\title{
RI 工業利用文献抄録集（57）
}

2668 マイクログラム量ウランからの核分裂 [5・2 生成セリウムの化学分離

Chemical Separation of Cerium Fission Products from Microgram Quantities of Uranium A. Albu-Yaron, D.W. Mueller, A.D. Suttle, Jr.: Anal. Chem., 41, (10) 1351 3 (1969)

Uの $1 \mathrm{ppm}$ 溶液 $1 \mathrm{~m} l$ に中性子を 4 時間照射したの ち, $\mathrm{HCl} 100 \mathrm{ml}, \mathrm{Ce}\left(\mathrm{NH}_{4}\right)_{2}\left(\mathrm{NO}_{3}\right)_{8}$ を正確に0.1〜0.2 $\mathrm{g}$ ，および $\mathrm{H}_{2} \mathrm{O}_{2}(30 \%)$ を 1 滴加え，陰イオン交換樹 脂柱（直径 $0.9 \mathrm{~cm}$, Dowex $2 \times 8 \mathrm{Cl}^{-}$型50 100 mesh 拈よび Dowex $1 \times 8 \mathrm{Cl}^{-}$型 200〜 400 mesh を括の招 の $2.5 \mathrm{~cm}$ 高さに充填）を通すと， Ce は樹脂に吸着さ れず流出する。流出液を蒸発乾固し, 水 $10 \sim 30 \mathrm{ml}$ に 溶解して $\mathrm{HNO}_{3} 12 \mathrm{ml}$ を加えたのち, $\mathrm{NaBrO}_{3} 0.35$ $\mathrm{g}$ を加えて Ce を $\mathrm{Ce}(\mathrm{IV})$ とする。この溶液に $\mathrm{KIO}_{3}$
の $\mathrm{HNO}_{3}$ 溶液を滴加すると $\mathrm{Ce}\left(\mathrm{IO}_{3}\right)_{4}$ が沈殿するの で, 沈殿を口過, 洗浄し, 放射能計测血にとり乾燥し て重量測定により化学収量を, 3 in. $\times 3$ in. $\mathrm{NaI}(\mathrm{Tl})$ （分解能 $6.8 \%$ ，計数効率 46 ～50\%) を用いて $\gamma$ 線スぺ クトルを求め, 放射性 $\mathrm{Ce}$ を算出する。 $\mathrm{Ce}$ の分離回 収率は95〜98\%，分離所要時間は70〜90分であった。

$\gamma$ 線スペクトル上の $0.294 \mathrm{MeV}$ のピークの半減期は $32.6 \sim 33.4$ 時間 $\left({ }^{143} \mathrm{Ce}, T_{1 / 2}=33\right.$ 時間) であり，また $0.145 \mathrm{MeV}$ の光電ピークは ${ }^{141} \mathrm{Ce}\left(T_{1 / 2}=32.5\right.$ 日) と ${ }^{144} \mathrm{Ce}\left(T_{1 / 2}=284\right.$ 日) によるものである。 ${ }^{97} \mathrm{Nb}(0.65$ $\mathrm{MeV}, T_{1 / 2}=72$ 分), ${ }^{95} \mathrm{Zr}\left(0.72 \mathrm{MeV}, T_{1 / 2}=65\right.$ 日) 線スペクトル上に認められたが，本法になんら影響を 及ぼさなかった。

(氏平)

\section{9 メスバウア分光学による Y 型ゼオライ [5・2] ト中の第一鉄イオンの可逆的酸化}

A Mössbauer Spectroscopic Study of the Reversible Oxidation of Ferrous Ions in Y Zeolite R.L. Garten, W.N. Deglass, M. Boudart:

J. Catalysis, 18, (1) 90〜107 (1970)

イオン交換法によって, 種々のゼオライト中に置換 された鉄イオンの状態とそれに及ぼす周囲の環境につ いての研究はメスバウア効果によって行なわれている が，そのなかでも，擬フォジサイトあるいはY型のゼ オライトについては触媒作用の観点から興味がある。 この作用を知るためにリンデ Y ゼオライト（Na を含 む型）を窒素気流中で, 硫酸第一鉄水溶液で処理し, 脱水し $\mathrm{Fe}^{2+}-\mathrm{Y} に し$, 酸素吸着, 真空排気等によって 起こる鉄イオン状態の変化をメスバウア効果で調べ
た。脱水した $\mathrm{Fe}^{2+}-\mathrm{Y}$ に存在する第一鉄イオンは 400 ${ }^{\circ} \mathrm{C}$ 酸素中では第二鉄イオンとなった。この場合, 2 個の鉄イオンに対して 1 個の酸素イオンが吸着した。

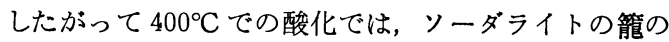
中で鉄-酸素-鉄の架橋結合が生成されることを示唆す る。このモデルを基礎として, 酸化状態の $\mathrm{Fe}^{2+}-\mathrm{Y}$ ゼ オライトに対する水, エタノール, アンモニア, ピリ ミジンの吸着状態を調べた。吸着酸素は $400^{\circ} \mathrm{C}$ の水素 還元で脱離して，スペクトルは完全に元に戻った。ま た $525^{\circ} \mathrm{C}$ の排気では，大部分の吸着酸素は取り除か れ, 脱水した $\mathrm{Fe}^{2+} \mathrm{Y}$ ゼオライトにみられる第一鉄イ オンとなったピークが現われた。湿った酸素の吸着 は, 室温でも, 部分的に第二鉄イオンの生成が認めら れた。

（豊島）
2670 陽イオン交換樹脂によるハフニウムお [5・2] よびジルコニウムの共存イオンからの分離

Cation-Exchange Separation of Hafnium and Zirconium from Accompanying Ions

J. Korkisch, K.A. Orlandini:

Talanta, 16, (1) 45〜49 (1969)

$\mathrm{HNO}_{3}, \mathrm{HCl}, \mathrm{H}_{2} \mathrm{SO}_{4}$ 酸性溶液に捄いて $\mathrm{Zr}$ と $\mathrm{Hf}$ は trioctylphosphine oxide (TOPO) を含む有機溶媒相 にきわめてよく抽出されることが見出されているが， 著者らはこの現象を利用して Zr, Hf の Dowex 50陽 イオン交換樹脂への吸着を低下させ他イオンと分離す ることを検討した。

TOPO を含まないメタノールー12 $\mathrm{N} \mathrm{HNO}_{3}$ 溶液に おいては $5 \mathrm{mg}$ までの $\mathrm{Zr}$, Hf の Dowex 50 陽イオン 交換樹脂柱 (長さ $25 \mathrm{~cm}$, 内径 $0.5 \mathrm{~cm}$, 流速 $0.3 \mathrm{ml} /$ 分)
に対する分配係数が $10^{3} \sim 10^{4}$ であるのに比し， $0.1 M$ TOPO を含むメタノール-12 $\mathrm{N} \mathrm{HNO}_{3}(19: 1)$ 溶液に おいては分配係数が 1 以下となり, 同じ条件で分配係 数が $10^{2} \sim 10^{4}$ である ${ }^{46} \mathrm{Sc},{ }^{169} \mathrm{Yb},{ }^{144} \mathrm{Ce},{ }^{241} \mathrm{Am},{ }^{54} \mathrm{Mn}$, ${ }^{59} \mathrm{Fe},{ }^{60} \mathrm{Co},{ }^{22} \mathrm{Na},{ }^{137} \mathrm{Cs},{ }^{45} \mathrm{Ca},{ }^{85} \mathrm{Sr},{ }^{44} \mathrm{Ti},{ }^{65} \mathrm{Zn}$ から分離で きる。メタノールを酢酸, テトラヒドロフラン, メチ ルグリコール, 水酢酸に代えて ${ }^{59} \mathrm{Fe},{ }^{44} \mathrm{Ti},{ }^{65} \mathrm{Zn}$ 以 外は差がほとんど認められなかった。また ${ }^{181} \mathrm{Hf},{ }^{95} \mathrm{Zr}$, ${ }^{44} \mathrm{Ti},{ }^{59} \mathrm{Fe},{ }^{60} \mathrm{Co}$ については鉱酸濃度あるいは TOPO 濃度が減少すると分配係数が著しく増大する傾向があ った。

（氏平） 
2671 トリウム工場流水中に含まれるラジウ $[5 \cdot 2]$ 厶同位体の分析

Analysis of Isotopic Radium in Thorium Mill Effluents

V.A. Kamath, P.P. Parekh:

Talanta, 16, (3) 345 50 (1969)

$\mathrm{Th} ， \mathrm{U}$ 製造工場に扮ける工程管理や揵康管理の 必要で, $\mathrm{Th}$ やUを含む陚料中の ${ }^{224} \mathrm{Ra}\left(T_{1 / 2}=3.64 \mathrm{y}\right)$ および ${ }^{228} \mathrm{Ra}\left(T_{1 / 2}=6.7 \mathrm{y},{ }^{232} \mathrm{Th} \stackrel{\alpha}{\longrightarrow}{ }^{228} \mathrm{Ra}\right)$ の定量法 を確立した。

固体試料を適当な方法で溶解し $50 \mathrm{~m} l$ としたのち, 3 時間者沸をつつ で生成している Rn を除去した。氷で急冷し冷却開始 後30分目に $\gamma$ 線スペクトルを測定し， $0.94 \mathrm{MeV}$ およ び2. $62 \mathrm{MeV}$ のピーク強度 $\left(C_{0.94}, C_{2.62}, \mathrm{cpm}\right)$ を求
め次式から ${ }^{224} \mathrm{Ra}$ および ${ }^{228} \mathrm{Ra}$ の存在量 $\left(R_{224}, R_{228}\right.$, $\mathrm{nCi}$ )を算出した。

$$
\begin{aligned}
& R_{224}=K_{1} C_{2.62} \\
& R_{228}=K_{2}\left[C_{0.94}-C_{2.62} \theta\right]
\end{aligned}
$$

$K_{1}, K_{2}: C_{0.94}$ あるいは $C_{2.62}$ として $10^{4} \mathrm{cpm}$ を与え る ${ }^{224} \mathrm{Ra}$ あるいは ${ }^{228} \mathrm{Ra} の ~ \mathrm{nCi}$ 数

$\theta:{ }^{224} \mathrm{Ra}-{ }^{208} \mathrm{~Pb}$ 系列が0. $94 \mathrm{MeV}$ および2. $62 \mathrm{MeV}$ 領域に与える放射能強度の比

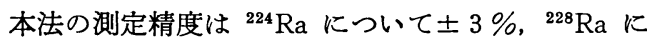

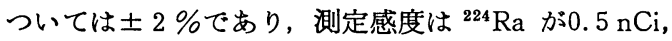
${ }^{228} \mathrm{Ra}$ が $2 \mathrm{nCi}$ であった。本法を組成が $\mathrm{ThO}_{2} 8.7 \%$, $\mathrm{RE}_{2} \mathrm{O}_{3} 59.4 \%, \mathrm{P}_{2} \mathrm{O}_{5} 27.0 \%, \mathrm{RbO} 0.26 \%$ である Indian Rare-Earths Factory, Alwaye の製品に応用し たところ, ${ }^{228} \mathrm{Ra}$ は $\mathrm{RE}$ 部に, ${ }^{224} \mathrm{Ra}$ はトリウムケー キ， $\mathrm{PbS}$ 部に分布していくことがわかった。（氏平）

\section{2 高速炉冷却システム中のセシウム-137 〔5•2〕 の定量}

Determination of Caesium-137 in Fast-reactor Coolant System

G. Oldham, A.R. Ware, D.J. Sykes:

Talanta, 16, (3) $430 \sim 2$ (1969)

冷却剤として金属液体（Na-K 合金）を使っている 高速师で，核分裂生成物が $\mathrm{Na}-\mathrm{K}$ 中に escape してく ることがある。とくに ${ }^{137} \mathrm{Cs}$ については半隇期が30年 と長いので，その escape について監視する必要があ る。そのため $\left(\mathrm{NH}_{4}\right)_{3} \mathrm{PO}_{4} \cdot 14 \mathrm{MoO}_{3} \cdot 4 \mathrm{H}_{2} \mathrm{O}(\mathrm{AMP})$ に よる高濃度 $\mathrm{Na}, \mathrm{K}$ 中の ${ }^{137} \mathrm{Cs}$ の捕集について検討し た。AMP 約 $120 \mathrm{mg}$ を磁器製ロ過ルツボ上にとり, これに ${ }^{137} \mathrm{Cs}$ を含む $\mathrm{Na}^{+}, \mathrm{K}^{+} / \mathrm{NH}_{4}^{+}$(AMP) 比が0.5〜 128 の溶液 $6 \mathrm{ml}$ を 30 滴/分の速さでそそぎ, $1 \mathrm{~N} \mathrm{HNO}_{3}$
$50 \mathrm{~m} l$ で洗浄した。AMP を $5 N$ アンモニア水で溶解 し水で $6 \mathrm{ml}$ とした。 $\mathrm{Na}^{+} / \mathrm{NH}_{4}^{+}$(AMP) が $0 \sim 128$, $\mathrm{K}^{+} / \mathrm{NH}_{4}^{+}$(AMP) $0 \sim 8.0$ の範囲で ${ }^{137} \mathrm{Cs}$ は $99 \%$ 以上 AMP に捕集されることが確認された。 $\mathrm{K}^{+} / \mathrm{NH}_{4}^{+}$ (AMP) か332.0では94.6〜90.6\%, $\mathrm{K}^{+} / \mathrm{NH}_{4}^{+}$(AMP) が64.0では70.7 68. 4\%と ${ }^{137} \mathrm{Cs}$ の捕集率は減少して いく。

(氏平)
2673 液体シンチレーション計数前に電解漉 縮を行なう方法によるトリチウムのルー チン定量法

A Routine Method for the Determination of Tritium by Electrolytic Concentration before Liquid Scintillation Counting

P. Metson:

Analyst, 94, (12) 1122〜9 (1969)

1954年以来の水爆実験により北半球の大気, 雨中に 含まれる Tレベルが $2 〜 3$ 倍にふえたため, 河川水や 雨中のT定量がルーチンに行なわれるようになった。 Tはエネルギーも低く，ごく微小濃度のTはとくに困 難であるが, 著者は大量の試料水をまず蒸留濃縮によ って $1 l$ にしたのち, これを内容積 $90 \mathrm{ml}$ の電解セル 中に流し込み $\mathrm{NaOH}$ 共存で電気分解を行ない（全液 量が $20 \mathrm{~m} l$ になるまでは $10 \mathrm{~A}, 20 \mathrm{ml} \sim 10 \mathrm{ml}$ 間は $7 \mathrm{~A}$, $10 \mathrm{~m} l \sim 5 \mathrm{~m} l$ 間は $3 \mathrm{~A})$ 約 $5 \mathrm{~m} l$ に濃縮した。濃縮水
の一部をとり T量をジオキサンーベースの 液体シンチ レーション計数法で測定し 試料水中の $\mathrm{T}$ 放射能強度 (A)を求めた。

$$
A=\frac{8.5 \times 10^{3} C P}{V R E}
$$

$こ こ て$

$C:$ 液体シンチレーションの計数值

$P$ : 試料水の体積濃縮比

$V$ : 計教に用いた濃縮水の体積

$R: \mathrm{T}$ の回収率

$E$ : 液体シンチレーションカウンターの計数効率

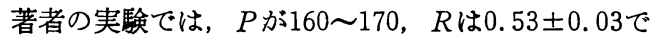
あり, 最近 2 年間の河川水. 雨中の Tレベルは100〜300 TU*であった。

* $10^{18}$ 個の ${ }^{1} \mathrm{H}$ 中に Tが 1 個存在する場合 1 Tritium unit (T.U.) といい3. $18 \mathrm{pCi} / l$ に相当する。

(氏平) 


\section{$[1 \cdot 1]$}

4503 Influence of a Rentrant Hole on a Measurement of Fast and Thermal Neutron Spectra F. McGirt, et al.: Nucl. Sci. \& Eng., 39, (1) 56〜66 (1970)

4504 Fast Neutron Cross Sections of Hafnium, Gadolinium, and Samarium

G.L. Sherwood, et al.: ibid., 39, (1) $67 \sim 80$ (1970)

4505 Release of Rare Gas Fission Products from Polymer Films

J. Scoble, et al.: Radiochim. Acta, 13, (2) 119 20 (1970)

4506 The Half-lives of Two Long-lived Nuclear Isomers, ${ }^{108 m} \mathrm{Ag}$ and ${ }^{192 m 2} \mathrm{Ir}$, and of ${ }^{137} \mathrm{Cs}$ and ${ }^{204} \mathrm{Tl}$

G. Harbottle: ibid., 13, (3) 132 4 (1970)

4507 Total Neutron Cross Sections of Ti-46 50 for Thermal and Epithermal Neutrons

E. Ya. Doil'nitsyn, et al.: Soviet Atomic Energy, 27, (2) 856 7 (1969)

4508 Simulating the Neutron-fission Spectrum with a Po-Be Sources

V.A. Kryzhanovskii, et al.: ibid., 27, (2) 876 $\sim 7$ (1969)

4509 The Neutron Cross Sections of the Cadmium Isotopes

V.P. Vertebnyi, et al.: ibid., 27, (4) $1117 \sim 8$ (1969)

\section{$[1 \cdot 2]$}

4510 Kinetic Deuterium Isotope Effect in the Reaction of Methyl Iodide with Thiosulfate Ion in Aqueous Solution

A.V. Willi, et al.: Canad. J. Chem., 48, (9) 1452 (1970)

4511 Nuclear Charge Dispersion of Light-mass Fission Products in the Fission of ${ }^{235} \mathrm{U}$ and ${ }^{238} \mathrm{U}$ by Medium-energy Protons

A.H. Khan, et al.: ibid., 48, (12) 1924 (1970)

4512 Studies of the Behaviour of Carrier-free Radioisotopes. IV. Some Behaviours of Carrierfree Silicon-31 from the View Point of Radiocolloid Formation

F. Ichikawa, et al.: Radiochim. Acta, 13, (2) $69 \sim 71$ (1970)

4513 Recoil Chemistry of ${ }^{51} \mathrm{Cr}$ in the Hexamminecobalt-(III) Complex and Chromate System N. Ikeda, et al.: ibid., 13, (2) 90 4 (1970)

4514 Recuit thermique des cristaux de pentacyanonitrosylferrate de sodium irradiés par neutrons
A. Rusi, et al.: ibid., 13, (2) 95 9 (1970)

4515 Chemical Effects of the $(n, \gamma)$ Reaction in Chloropentaammine Complexes of Cobalt(III), Rhodium(III) and Iridium(III)

E.R. Gardner, et al.: ibid., 13, (2) $100 \sim 4$ (1970)

4516 Chemical Effects of Neutron-Induced Nuclear Reactions in Halates and Related Compounds. III. The $(n, \gamma)$ and $(n, 2 n)$ Reactions in Iodates

F. Ambe, et al.: ibid., 13, (2) 105 11 (1970)

4517 Some Cumulative Mass-Yields from the Fission of ${ }^{238} \mathrm{U}$ by $3 \mathrm{MeV}$ Neutrons

S.J. Lyle, et al.: ibid., 13, (2) $167 \sim 8$ (1970)

4518 Measurement of Isomeric Yield Ratios in Nuclear Reactions

J. Ahumada, et al.: ibid., 13, (3) $121 \sim 31$ (1970)

4519 Investigation of the Reactions of the Recoil Carbon-14 Atoms in Some Heterogeneous Mixtures

M.F. Barakat, et al.: ibid., 13, (3) $152 \sim 6$ (1970)

4520 On the Substitution of $\mathrm{Cr}$ (III) in $\mathrm{Cr}$ (III) Oxinate Crystals by Dopant ${ }^{60} \mathrm{Co}^{2+}$ Ions E. Lazzarini, et al.: ibid., 13, (3) 156 9 (1970)

4521 The Reaction of ${ }^{82} \mathrm{Br}$ Activated by Isomeric Transition with $\mathrm{CH}_{4}$ in the Gaseous Phase E. Tachikawa, et al.: ibid., 13, (3) $159 \sim 63$ (1970)

4522 Determination of Radium and Thorium X in a Layer of Barium Sulfate

A.G. Andreev, et al.: Soviet Radiochem., 11, (1) $72 \sim 6$ (1969)

4523 Structure of the Surface of Radioactive Crystals of $\mathrm{Ba}, \mathrm{Sr}$, and $\mathrm{Ca}$ Sulfates

V.V. Gromov, et al.: ibid., 11, (1) $81 \sim 3$ (1969)

4524 Kinetics of Ion-Exchange Sorption of Yttrium from Solutions of Salts of Certain Elements I.F. Bodashkova, et al.: ibid., 11, (2) 129 32 (1969)

4525 Solvolysis of Uranyl Nitrate in Alcohol Solutions in the Presence of Tridecylamine V.M. Vdovenko, et al.: ibid., 11, (2) 229 32 (1969)

4526 Extraction of Technetium and Rhenium with 8-Mercaptoquinoline

V.I. Kuznetsov, et al.: ibid., 11, (2) $233 \sim 5$ (1969)

4527 Interaction of Thorium Tungstate with Sodium and Lithium Tungstate 
V.K. Trunov, et al.: ibid., 11, (2) $239 \sim 40$ (1969)

4528 Investigation of the Hydrolysis of Antimony (V) in Solutions of Hydrochloric Acid with the Aid of the Mössbauer Effect

V.A. Bryukhanov, et al.: ibid., 11, (3) 356 $\sim 9$ (1969)

4529 Chemical Behavior of Radioactive Rhenium Atoms during the Thermal Annealing of $\mathrm{NH}_{4} \mathrm{ReO}_{4}$ Crystals, Irradiated with $660 \mathrm{MeV}$ Protons

N.G. Zaitseva, et al.: ibid., 11, (3) $361 \sim 3$ (1969)

4530 Investigation of Redox Reactions of the Actinide Elements. XI. Kinetics of the Reduction of Uranium(VI) and Neptunium(VI) by Solid Metals

Anon: ibid., 11, (4) 414 6 (1969)

4531 Electrolytic Reduction of Uranyl in Oxalate Solutions

V.F. Peretrukhin, et al.: ibid., 11, (4) 417 21 (1969)

4532 Absorption Spectra of Uranium Oxides in the Region of Compositions from $\mathrm{UO}_{2.50}$ to $\mathrm{UO}_{2 \cdot 64}$

T.A. Il'inskaya, et al.: ibid., 11, (4) $422 \sim 5$ (1969)

4533 Investigations of Redox Reactions of the Actinide Elements. XIII. Kinetics of the Reactions of Neptunium (IV)-Plutonium (VI) in Perchlorate Solutions

A.G. Rykov, et al.: ibid., 11, (4) $443 \sim 4$ (1969)

4534 Radiocolloids and the Solubility Product M.N. Haissinsky: ibid., 11, (4) 469 70(1969)

4535 Hydroxide Collectors in Radiochemistry. IV. Two Approaches to Describing the Secondary Sorption of Ionic Microcomponents

Yu. V. Egorov: ibid., 11, (5) 482 7 (1969)

4536 Establishment of an Organic Bond by a Hot Phosphorous-32 Atom in a Mixture of $\mathrm{CCl}_{4}$ $\mathrm{C}_{6} \mathrm{H}_{6}$

N.I. Gabov: ibid., 11, (5) 558 61 (1969)

4537 Reactions of $\mathrm{T}^{+}$Ions with Solid Pyridine

L.P. Firsova, et al.: ibid., 11, (5) $562 \sim 7$ (1969)

4538 Reactions of Accelerated Tritium Ions in Benzene-Naphthalene Mixtures

L.P. Firsova, et al.: ibid., 11, (5) $568 \sim 72$ (1969)

4539 Investigation of Binary Oxides of Erbium and Uranium
L.M. Kovba, et al.: ibid., 11, (5) $585 \sim 7$ (1969)

4540 The State of Microquantities of Niobium-95 and Technetium-99 in Sea Water

V.I. Spitsyn, et al.: ibid., 11, (5) 592 4 (1969)

4541 Mechanism of the Distribution of Mineral Acids between Aqueous Solutions and the Diisoamyl Ester of Methylphosphonic Acid (DAMP). I. Interactions in the System Hydrogen Fluoride-DAMP

V.M. Vdovenko, et al.: ibid., 11, (5) $595 \sim 8$ (1969)

4542 Radiation Chemical Transformations of Atoms in Single Crystals of $\mathrm{KCl}$

R.V. Bogdanov, et al.: ibid., 11, (5) 599 600 (1969)

4543 Distribution of Phosphorus Recoil Atoms According to Valence Forms in Deformed Alkali Halide Crystals

R.V. Bogdanov, et al.: ibid., 11, (5) $604 \sim 5$ (1969)

4562 (p.1143, 右), 4626 (p. 1146, 左),

4627 (p.1146, 左), 4629 (p.1146, 左)

$[2 \cdot 1]$

4544 Teilautomatisierung der Bedienung eines Van-de-Graaff-Beschleunigers

E. Richter, et al.: Kernenergie, 13, (4) 122 $\sim 4$ (1970)

4545 Bremsstrahlenquellen auf Promethiumwolframatbasis

F. Weigel, et al.: Radiochim. Acta, 13, (2) 63 4 (1970)

4546 Betatron Radiographic Techniques for Titanium Billets

F.J. Sattler: Material Evaluation, 28, (2) 37 $\sim 42$ (1970)

4547 Characteristics and Applications of Fluorometallic Intensifying Screens in Radiographic Testing

T. Takizawa, et al.: ibid., 28, (3) $49 \sim 54$ (1970)

4548 Dimensional Measurements of Cylindrica Specimens Using Neutron Radiography S.J. Basham, et al.: ibid., 28, (6) $140 \sim 4$ (1970)

4549 Mössbauer Spectra and Electric Dipole Moments of Organotin(IV) Complexes with Organic Ligands 
F. Patricia Mullins: Canad. J. Chem., 48, (11) 1677 (1970)

4550 Nondestructive Assay of Plutonium Reactor Fuel by Gamma-ray Measurements Using Online Computer Control

R.W. Brandenburg, et al.: Material Evaluation, 28, (4) $77 \sim 80$ (1970)

4551 Application of Coulomb Backscattering of the Heavy Charged Particles. II. Chemical Analysis of Surface Layers

A. Turos, et al.: Nukleonika, 14, (4) 319 34 (1969)

4552 Liquid Helium Cryostat for Mössbauer Experiments

S. Lazarski, et al.: ibid., 14, (9/10) 947 50 (1969)

4553 Effect of Errors in Measurements on Results of Differential Interpretation of $\boldsymbol{\gamma}$-logs

K.I. Volodin, et al.: Soviet Atomic Energy, 27, (2) 869 72 (1969)

4554 Determination of the Moisture Content of Materials from the Elastic Scattering of Fast Neutrons

G.A. Ivashchenko, et al.: ibid., 27, (3) 979 80 (1969)

\section{[2.4]}

4555 Investigation of Interaction of Fast Tritium Ions with Titanium

V.I. Strizhak, et al.: Soviet Atomic Energy, 27, (2) $878 \sim 80$ (1969)

\section{[3.1]}

4556 Effect of Gamma Radiation on Ion Exchange Resins. I. Irradiation Damage of Functional Groups in the Strong Base Anion Exchange Resin Zerolit FF-IP

A. Basiński, et al.: Nukleonika, 14, (5) 509 〜19 (1969)

4557 Softening of Austenitic Aging Steel by Neutron Irradiation

V.A. Nikolaev: Soviet Atomic Energy, 27, (3) $962 \sim 3$ (1969)

[3.2]

4558 Radiation Chemistry of Gaseous Oxygen:

Experimental and Calculated Yields

C. Willis, et al.: Canad. J. Chem., 48, (10) 1505 (1970)

4559 Radiolysis of Air and Nitrogen-Oxygen Mixtures with Intense Electron Pulses: Determination of a Mechanism by Comparison of Measured and Computed Yields

C. Willis, et al.: ibid., 48, (10) 1515 (1970)
4560 Electron Spin Resonance Studies of Irradiated Nitrous Oxide

D.R. Smith, et al.: ibid., 48, (12) 1803 (1970)

4561 Study of the Radiation Stability of a Number of Vinyl Aromatic Polymers and Copolymers by the Method of IR Spectroscopy

O.A. Gunder, et al.: Soviet Radiochem., 11, (1) $116 \sim 9$ (1969)

\section{[3.3]}

4562 Emission from Benzene Excited by Pulse Radiolysis

A.R. Horrocks: Canad. J. Chem., 48, (6) 1000 (1970)

4563 Radiolysis of Ethane. I. Liquid Phase at $195^{\circ} \mathrm{K}$ with Added Cyclopentene

P.T. Holland, et al.: ibid., 48, (7) 1078 (1970)

4564 Radiolysis of Ethyl Iodide-chloromethane Mixtures

R.M. Lebranc, et al.: ibid., 48, (8) 1273 (1970)

4565 Radiation-induced Oxidation of 2-Propanol by Hydrogen Peroxide in Aqueous Solutions

C.E. Burchill, et al.: ibid., 48, (8) 1232 (1970)

4566 Pulse Radiolysis of Ethanol

J.W. Fletcher, et al.: ibid., 48, (11) 1645 (1970)

4567 Yield of Free-ions in the Radiolysis of Formamide, a Liquid of Very High Dielectric Constant

D.A. Head, et al.: ibid., 48, (11) 1657 (1970)

4568 Electron Spin Resonance Studies of Radiation Damage. Part III. Gamma Irradiated Acetonitrile

F.P. Sargent: ibid., 48, (11) 1780 (1970)

4569 Die Stahlenchemie phosphororganischer Verbindungen

H. Drawe: Radiochim. Acta, 13, (2) 81 9 (1970)

4570 Experimental Problems of the Radiation Behavior of Polymers

F.A. Makhlis: Soviet Atomic Energy, 27, (4) 1084 91 (1969)

$$
\text { [4.1] }
$$

4571 Measurements of the ${ }^{14} \mathrm{C}$ Tracer Used in Oil Wells

E. Wagiel, et al.: Nukleonika, 14, (2) 197 204 (1969) 


\section{$[4 \cdot 2]$}

4572 Flotation of Anions Using Cationic Surfacants. II. Flotation of Perrhenates W. Charewicz, et al.: Nukleonika, 14, (6) 607 16 (1969)

4573 Flotation of Anions Using Cationic Surfacants. III. Flotation of Chloroaurates W. Charewicz, et al.: ibid., 14, (7/8) 799 806 (1969)

\section{[5.1]}

4574 Nondestructive Radioactivation Analysis of Al-cans Used for Irradiations in the RA Reactor at Vinča, Yugoslavia

M. Kakaš, et al.: Radiochim. Acta, 13, (2) 75 81 (1970)

4575 Theory of Partial Interpretation in Activation Analysis

N.V. Zinov'ev: Soviet Atomic Energy, 27,

(2) $836 \sim 8$ (1969)

4576 Use of Neutron Activation Analysis for Determining Fluorite Content in Mining Trolleys V.I. Prokopchik, et al.: ibid., 27, (2) 883 5 (1969)

4577 Selectivity of $\gamma$-Activation Analysis

M.G. Davydov, et al.: ibid., 27, (3) $940 \sim 3$ (1969)

4578 Photoactivation Analysis of Antimony-Zirconium Ionite

L.A. Kotel'nikov, et al.: Soviet Radiochem., 11, (2) 253 5 (1969)

4579 Determination of Rhenium and Germanium by the Neutron Activation Method

G.N. Razumova, et al.: ibid., 11, (3) $345 \sim 7$ (1969)

4580 Determination of Trace Impurities in Indium Antimonide by a Neutron Activation Method I. Ya. Vasil'ev, et al.: ibid., 11, (5) 554 7 (1969)

4581 Photoactivation Analysis of a PhosphorusZirconium Ion-Exchange Resin

L.A. Kotel'nikov, et al.: ibid., 11, (5) 601 3 (1969)

4590 (p. 1144, 右), 4597 (p.1145, 左)

\section{[5.2]}

4582 Studies on the Matrix and Grain-Size Effects in the Non-dispersive $\mathrm{X}$-ray Fluorescence Analysis of Geological Samples

B. Dziunikowski, et al.: Nukleonika, 14, (6) 667 76 (1969)

4583 Use of the Nuclear Reaction ${ }^{18} \mathrm{O}(p, \gamma)^{19} \mathrm{~F}$ to Study the Distribution of Oxygen in Oxide
Films

N.A. Skakun, et al.: Soviet Atomic Energy, 27, (4) $1121 \sim 2$ (1969)

\section{$[6 \cdot 1]$}

4584 A Variational Approach for the Determination of Neutron Flux Spectra from Detector Activation

R.W. Brandon, et al.: Nucl. Sci. \& Eng., 39, (2) 151 62 (1970)

4585 Application of a Slow-scintillation Component of Stilbene in Dosimetry of Mixed Radia ${ }^{-}$ tion

S. Pszona: Nukleonika, 14, (2) 205 10 (1969)

4586 The Kinetics of Oxidation of Ferrocyanide and Reduction of Ferricyanide Ions by $\gamma$-rays J. Sobkowski: ibid., 14, (3) 253 9 (1969)

4587 Beta-ray Spectroscopy Using a Hollow Plastic Scintillator. Part I

R. Szepke: ibid., 14, (4) 407 12 (1969)

4588 Measurements of ${ }^{43} \mathrm{~K},{ }^{44} \mathrm{~K}$ and ${ }^{45} \mathrm{~K}$ Gamma Rays

R.E. Larson: Radiochim. Acta, 13, (2) 61 2 (1970)

4589 The Radio-Frequency (Oscillometric) Alcoholic Chlor Benzene Dosimeter

Zs. Horváth, et al.: ibid., 13, (3) 150 2 (1970)

4590 Determination of Carbon in the Reticular Substructure of Uranium by the Method of Activation Autoradiography

A.A. Bachvar, et al.: Soviet Atomic Energy, 27, (3) 925 8 (1969)

4591 Sensitivity of $\beta$-Radiation End-Window Counters of the MST-17, SI-2B, and SBT-7 Types to the $\gamma$ - and Conversion Radiation of ${ }^{238} \mathrm{Pu}$ and ${ }^{241} \mathrm{Am}$

V.V. Gryzina, et al.: Soviet Radiochem., 11, (3) $364 \sim 5$ (1969)

4503 (p.1141, 左), 4637 (p.1146, 右)

\section{$[6 \cdot 2]$}

4592 Gasszintillationsdetektor mit 100-at-Heliumfüllung

D. Schmidt, et al.: Kernenergie, 13, (5) 148 〜0 (1970)

4593 Semiconductor Position-sensitive Detectors

J. Chwaszczewska, et al.: Nukleonika, 14, (1) 11 5 (1969)

4594 Scintillation Properties of Essential Oil Solu tions

J. Kucharski: ibid., 14, (5) 475 84 (1969) 
4595 A Simple Gas-Flow Proportional Counter D.J. Malcolme-Lawes, et al.: Radiochim. Acta, 13, (2) 114 6 (1970)

4596 Study of Various Characteristics of Ceramic Fuel Elements with a Semiconductor GammaSpectrometer

E.F. Davydov, et al.: Soviet Atomic Energy, 27, (3) $964 \sim 5$ (1969)

4597 The Dosage Sensitivity of Activation Detectors Made from Copper and Phosphorous in Relation to Neutrons of Various Spectra G.M. Obaturov, et al.: ibid., 27, (3) $981 \sim 4$ (1969)

4598 Combined Air-equivalent Scintillators for Xray and $\gamma$-ray Dosimetry

M.I. Arsaev, et al.: ibid., 27, (4) 1098 9 (1969)

4599 A Cerenkov Detector for the Method of "Delayed Recording"

I.V. Sanin, et al.: ibid., 27, (4) 1125 6 (1969)

4600 Schaltung zur Nulleffektsubtraktion bei digitalen Kernphysikalischen Meßgeräten

M. Seifart: Kernenergie, 13, (3) $87 \sim 90$ (1970)

4601 Die "Kleinen Strahlungsmeßgeräte VA-M141" des VEB RFT Meßelektronik Dresden K.H. Berger: ibid., 13, (5) 162 6 (1970)

4602 Die Linearverstärker/Analysator VA-V-100 des VEB RFT Meßelektronik Dresden K.H. Berger: ibid., 13, (6) $181 \sim 3$ (1970)

4603 Equipment for Investigation of Short-lived Activities Excited by Fast Neutrons from a Neutron Generator

E. Rurarz, et al.: Nukleonika, 14, (4) $337 \sim$ 48 (1969)

4604 A New Single-channel Pulse-height Analyser J. Bialkowski: ibid., 14, (5) 549 54 (1969)

\section{[6.4]}

4605 Determination of the Minimal Dimensions of Models for Gamma-gamma Measurements J. Charbuciński, et al.: Nukleonika, 14, (7/8) $869 \sim 82$ (1969)

\section{$[7 \cdot 1]$}

4606 Volatilité du nitrate, chlorure et sulfure mercurique et preparation de sources radioactives de ${ }^{203} \mathrm{Hg}$

J. Grossoleil, et al.: Canad. J. Chem., 48, (5) 705 (1970)

4607 Application of the $200 \mathrm{kV}$ Accelerator for the Production of "Drive-in" Targets from Gaseous Radioactive Xenon

J. Ludziejewski, et al.: Nukleonika, 14, (3) $247 \sim 50$ (1969)

4608 Separation of Europium from Irradiated $\mathrm{UO}_{2}-\mathrm{Mg}$ Fuel Samples for Burn-up Determination W. Smulek: ibid., 14, (5) 521 35 (1969)

4609 Production of Carrier-free Radioisotopes from Targets Irradiated with Deuterons or $\alpha$-paticles in the U-120 Cracow Cyclotron. I. Preparation of Cadmium, indium, and Tellurium Radioisotopes

S. Kopta, et al.: ibid., 14, (6) 619 25 (1969)

4610 Production of Carrier-free Radioisotopes from Targets Irradiated with Deuterons or $\alpha$-particles in the U-120 Crakow Cyclotron. Part II . Preparation of Radioisotopes of Gadolinium, Samarium, and Thulium from Targets of $\mathrm{Sa}^{-}$ marium, Neodymium and Holmium

S. Kopta, et al.: ibid., 14, (7/8) 789 96 (1969)

4611 Application of the Gas Loop for Production of Radioactive Isotopes in the Reactor J. Ludziejewski, et al.: ibid., 14, (7/8) 825 9 (1969)

4612 Abtrennung von ${ }^{103 m} \mathrm{Rh}$ von ${ }^{103} \mathrm{Pd}$ in Form eines Isotopengenerators

H. Bernhard, et al.: Radiochim. Acta, 13,

(3) $134 \sim 8$ (1970)

4613 Application de l'électrolyse interne à compartiments séparés à l'analyse radiochimique.

I. Etude critique des différents paramètres Francis van Kote, et al.: ibid., 13, (3) 139 44 (1970)

4614 Application de l'électrolyse interne à compartiments séparés à l'analyse radiochimique. II. Séparation de certains produits de fission Francis van Kote, et al.: ibid., 13, (3) 145 9 (1970)

4615 Retention of ${ }^{80 m} \mathrm{Br}$ in $(n, \gamma)$ Irradiated Cadmium Bromate Crystals

H.J. Arnikar, et al.: ibid., 13, (3) $164 \sim 7$ (1970)

4616 Radioactive Isotopes of Tellurium as Indicators of the Completeness of the Isolation of Polonium

L.A. Teplykh: Soviet Radiochem., 11, (1) $120 \sim 1$ (1969)

4617 Generators of Yttrium-90 and Lanthanum140

N.B. Mikheev: ibid., 11, (1) 125 6 (1969) 
4618 Experiments on the Chemistry of Element 104-Kurchatovium. I. Development of a Method for Studying Short-Lived Isotopes

I. Zvara, et al.: ibid., 11, (2) 153 62 (1969)

4619 Experiments on the Chemistry of Element 104-Kurchatovium. II. Chemical Investigation of the Isotope which Undergoes Spontaneous Fission with a Half-Life of $0.3 \mathrm{sec}$

I. Zvara, et al.: ibid., 11, (2) 161 70 (1969)

4620 Experiments on the Chemistry of Element 104-Kurchatovium. III. Chemical Apparatus in the Cyclotron Beam

Yu. T. Chuburkov, et al.: ibid., 11, (2) 171 $\sim 81$ (1969)

4621 Isolation of Carrier-Free Yttrium-88 from a Strontium Target

V.I. Levin, et al.: ibid., 11, (2) 201 5 (1969)

4622 Characteristics of Loop Preparation of Berkelium in a Reactor

M.A. Bak, et al.: ibid., 11, (3) 316 9 (1969)

4623 Extraction of Transplutonium Elements by Butyric Acid

V.A. Bochkarev: ibid., 11, (3) 331 4 (1969)

4624 Experiments on the Chemistry of Element 103: Adsorption of the Chloride from a Gas Flux

Yu. T. Chuburkov, et al.: ibid., 11, (4) 386 〜9 (1969)

4625 Production of ${ }^{234} \mathrm{Th}\left(\mathrm{UX}_{1}\right)$ by the Method of Partition Chromatography

B.I. Shestakov, et al.: ibid., 11, (4) $461 \sim 2$ (1969)

4626 Study of the Adsorption of Americium on the Surface of Polished Platinum

A.G. Samartseva: ibid., 11, (5) 489 95(1969)

4627 Separation of Zirconium and Hafnium from Other Elements by Adsorption on Silica Gel from Mixed Solutions

R. Tsaletka, et al.: ibid., 11, (5) 496 500 (1969)

4628 Isolation of the Isotope Thorium-229 and Investigation of Its Spectroscopic Properties V.N. Egorov, et al.: ibid., 11, (5) $542 \sim 6$ (1969)

\section{$[7 \cdot 2]$}

4629 Protonated Cyclopropanes. IV. Trigluoroacetolysis of $1{ }^{14} \mathrm{C}-1$-propyltosylate

C.C. Lee, et. al.: Canad. J. Chem., 48, (6) 1025 (1970)

4630 Use of Ozone for Synthesis of Alkali Metal Periodates Labeled with the Isotopes ${ }^{131} \mathrm{I},{ }^{133} \mathrm{I}$, and ${ }^{135} \mathrm{I}$
V.K. Isupov, et al.: Soviet Radiochem., 11, (2) $258 \sim 61$ (1969)

4631 Radiochemical Investigation of the Products from the Spallation of Praseodymium Nuclei by Protons with an Energy of $660 \mathrm{MeV}$

A.K. Lavrukhina, et al.: ibid., 11, (3) $320 \sim$ 7 (1969)

\section{[7·3]}

4632 New Isotopes ${ }^{158} \mathrm{Tm}$ and ${ }^{160} \mathrm{Tm}$

F.W.N. de Boer, et al.: Radiochim. Acta, 13. (2) $118 \sim 9$ (1970)

[8.1]

4633 Die Berechnung des Strahlungsfeldes einer gerichtet strahlenden Punktquelle von $\gamma$ Quanten mit der Momentenmethode

F.W. Krüger: Kernenergie, 13, (2) $47 \sim 54$ (1970)

4634 Micro- and Single-crystalline LiF: Mg, Ti Phosphor and Its Application in Radiation Dosimetry

M. Jasińska, et al.: Nukleonika, 14, (9/10) 995 1008 (1969)

4635 Amaranth as a Low Level Gamma Ray Dosimeter

P.M. Oza, et al.: Radiochim. Acta, 13, (2) $117 \sim 8$ (1970)

4636 Dosimetry of Intense $\gamma$-fluxes by Colored Glass

V.M. Trotimov, et al.: Soviet Atomic Energy, 27, (2) $873 \sim 5$ (1969)

4637 Separate Determination of Fast-neutron and $\gamma$-ray Dose by Means of Polymer Films

Ya. I. Lavrentovich, et al.: ibid., 27, (4) 1054 $\sim 8$ (1969)

\section{$[8 \cdot 2]$}

4638 Strahlenschutz in Kernkraftwerk Rheinsberg W. Gerullis, et al.: Kernenergie, 13, (7) 209 $\sim 26$ (1970)

4639 Study of Gamma Cells in Powerful Fluxes of Gamma Radiation

A.G. Vasiliev, et al.: Soviet Atomic Energy, 27, (3) $985 \sim 6$ (1969)

\section{[8.3]}

4640 Die Abschirmung von $\gamma$-Strahlung durch Schwerstbetone mit einer Dichte zwischen 3.2 und $3.8 \mathrm{~g} / \mathrm{cm}^{3}$.

F.W. Krüger: Kernenergie, 13, (6) 172 8 (1970)

4641 Die Abschirmung schneller Brutreaktoren L. Albrecht, et al.: ibid., 13, (8) $237 \sim 42$ (1970) 


\section{RI 農学・生物学利用文献抄録集（65）}

\section{Zeatin の先駆体}

$6-(\gamma, \gamma$-Dimethylallylamino $)$ Purine as a Precursor of Zeatin

George A. Miura, Carlos O. Miller: Dept. of Botany, Univ. of Indiana, Bloomington, Ind., Plant Physiol., 44, (3) 372 6 (1969)

$6-(\gamma, \gamma$-dimethylallylamino $)$ purine $-8-{ }^{14} \mathrm{C}, 250,000$ cpm を含有する Hagem's 修正培養液で担子菌ショウ 口（Rhizopogon roseolus）を数日間培養した。ペー パークロマトグラフィおよび過マンガン酸カリ, 臭素 による酸化処理の結果, 培地から ${ }^{14} \mathrm{C}$ 標識 Zeatin ribonucleoside が検出された。同様に adenine $-8-^{14} \mathrm{C}$, 6-chloropurine $-8{ }^{-14} \mathrm{C}$, hypoxanthine $-8{ }^{-14} \mathrm{C}$ ならびに 4-amino-5-imidazole carboxamide- $-2-{ }^{14} \mathrm{C}$ をそれ゙れ 培養液に加えて担子菌を培養したとき，これら ${ }^{14} \mathrm{C}$ 標 識化合物はいずれも Zeatin ribonucleoside に取り込 まれた。

(武長)

\section{8 発芽種子，幼植物における $\mathbf{S r}$ の移動性}

Strontium Mobility in Germinating Seeds and Plants

C.R. Creger, W.S. Allen: Dept. of Biochem. and Biophys., Texas A \& M Univ., College Station,

Texas, Plant Physiol., 44, (3) 439 41 (1969)

インゲン幼植物を ${ }^{89} \mathrm{Sr}$ 含有水耕液で培養した。培養 1 時間後に植物体内から ${ }^{89} \mathrm{Sr}$ が検出され, 引続き直線 的に吸収は増加し, 34時間以後吸収速度は急激に増し た。インゲン種子を ${ }^{89} \mathrm{Sr}$ 水耕液に 24 時間浸漬し，そ の後の ${ }^{89} \mathrm{Sr}$ の消長を調べた結果, 種子中 ${ }^{89} \mathrm{Sr}$ の約 75 \%が種皮に分布し, 生育が進むに従って減少した。子 葉, 種子胚軸の ${ }^{89} \mathrm{Sr}$ 含量は一定速度で増加し, 第 1 , 2 葉から処理 7 日目に ${ }^{89} \mathrm{Sr}$ が検出され，増加した。さ らにワタ幼植物について同様の吸収実験を行ない, 第 $3 ， 4$ 葉中の ${ }^{89} \mathrm{Sr}$ は第 $1 ， 2$ 葉拉よび茎の ${ }^{89} \mathrm{Sr}$ が移 行, 分布したものであることが示された。（武長）

\section{9 溶質のクチクラ膜透過}

Penetration of Iron and Some Organic Substances through Isolated Cuticular Membranes

S. Kannan: Dept. of Horticulture, Michigan State Univ., East Lansing, Plant Physiol., 44, (4) 517 21 (1969)

トマト果実とマサキ葉の背, 腹面からクチクラ膜を 酵素的に分離し, ${ }^{59} \mathrm{FeSO}_{4}$ と ${ }^{59} \mathrm{FeEDDHA}$ の ${ }^{59} \mathrm{Fe} の$ 膜透過と $10 \mathrm{~m} M$ 尿素添加の影響を検討した。 ${ }^{59} \mathrm{FeSO}_{4}$ の ${ }^{59} \mathrm{Fe}$ は ${ }^{59} \mathrm{FeEDDHA} よ り$ 速やかに透過し，尿 素の存在は両鉄塩の ${ }^{59} \mathrm{Fe}$ 透過を抑制した。またトマ ト果実クチクラ膜内での ${ }^{59} \mathrm{Fe}$ 固定は EDDHA によっ て減少した。 ${ }^{14} \mathrm{C}$ 標識 ethylene, glycol, glycerol, Dribose, D-glucose, sucrose, EDTA, EDDHA などの 透過速度は分子量に関係することが示唆され，透過恒 数も 3 種のクチクラ膜でそれぞれ異なった。マサキ葉 背面クチクラを通しての透過は全溶質とも腹面クチク ラより大であった。

（武長）

\section{0 トウコマ植物における ricinine の代謝}

Metabolism of the $\alpha$-Pyridone Ring of Ricinine in Ricinus communis $\mathrm{L}$

G.R. Waller, J. L-C. Lee: Dept. of Biochem., Oklahoma Agr. Exper. Station, Oklahoma State Univ., Plant Physiol., 44, (4) 522 6 (1969)

トウゴマ植物体の茎に ricinine-3,5-14 C を注入し, 6 か月間にわたって ricinine 中の放射能量を追跡し た結果, ricinin $\mathrm{e}^{-14} \mathrm{C}$ の比放射能は時間の経過に伴っ て希釈, 減少した。また種子中 ricinine $\mathrm{e}^{-14} \mathrm{C}$ の比放射 能は葉や花の $3 \sim 10$ 倍で, 容易に移行することが認め られた。生体内に打ける ricinine $-3,5-{ }^{-14} \mathrm{C}$ の呼吸 ${ }^{14} \mathrm{CO}_{2}$ への変化は明, 暗両所で行なわれ, ricinine の $\alpha$-pyridone 環は開裂することが示された。種々の組 織中の ricinin $\mathrm{e}^{-14} \mathrm{C}$ 含量を比較した結果, 黄色葉か ら痕跡程度検出され, 黄色葉も ricinine-3,5- ${ }^{-14} \mathrm{C}$ を ${ }^{14} \mathrm{CO}_{2}$ に代謝しうることが示された。

（武長）

\section{1 カラシ油配糖体の生合成}

Biosynthesis of Mustard Oil Glucosides: Sodium Phenylacetothiohydroximate and Desulfobenzylglucosinolate, Precursors of Benzylglucosinolate in Tropaeolum majus L

E.W. Underhill, L.R. Wetter: Prairie Regional Lab., Natl. Res. Council of Canada, Saskatoon, Plant Physiol., 44, (4) 584〜90 (1969)

ノウゼンハンン茎に desulfobenzyl glucosinolate$1-\mathrm{G} 1-{ }^{14} \mathrm{C},-\mathrm{G} 1-{ }^{14} \mathrm{C},-1-{ }^{14} \mathrm{C}$, sodium phenylacetothiohydroximate $-2-{ }^{14} \mathrm{C}-{ }^{35} \mathrm{~S}$, DL-phenylalanine $-3-{ }^{14} \mathrm{C}$, $\mathrm{D}$-glucose- $\mathrm{G}-{ }^{14} \mathrm{C}, 1$-thioglucose- $\mathrm{G}-{ }^{14} \mathrm{C}$ をそれぞれ注 入し，カラシ油配糖体 benzylglucosinolate の生合成 を研究した。benzylglucosinolate の thioglucosyl 部 分は 1-thioglucose からではなくて phenylacetothiohydroximate $の$ glucosylationによって生成されるこ とが認められた。また配糖体生合成の最終段階として desulfobenzylglucosinolate の sulfation が行なわれ ることが示された。 (武長)

\section{2 コムギのチッ素同化 II. 微量要素の影響}

Nitrogen Assimilation and Protein Synthesis in Wheat Seedlings as Affected by Mineral Nutrition. II. Micronutrients

J.E. Harper, G.M. Paulsen: Dept. of Agron., Kansas State Univ., Manhattan, Kansas, Plant Physiol., 44, (5) 636 40 (1969)

冬コムギ (Triticum aestivum L.) 幼植物の硝酸 還元酵素活性は $\mathrm{Mo}, \mathrm{Zn}, \mathrm{Cl}$ 欠乏によって減少した。 体内の硝酸含量は Mo 欠で増加, $\mathrm{Zn}$ 久で減少し, 他 の微量要素には影響されなかった。グルタミン酸脱水 素酵素活性は Mo 欠, グルタミンシンセターゼ活性 は $\mathrm{Cu}$ 欠によってのみ, それぞれ減少し, グルタミン 酸ーオキザロ酢酸トランスアミナーゼ活性はいかなる 微量要素の欠乏に多影響されなかった。 ${ }^{14} \mathrm{C}$ ーロイシン の葉中タンパクへの取込みは Mo 欠で増加, $\mathrm{Cu}$ 久で 減少したが, 幼植物体内のタンパク含量は微量要素処 理によってほとんど影響されなかった。

（武長） 


\section{3 クロレラの尿素代謝}

Metabolism of Urea by Chlorella vulgaris

R.C. Hodson, J.F. Thompson: Section of Genet., Develop. and Physiol., Div. of Biol. Sci., Cornell Univ., Plant Physiol., 44, (5) 691 6 (1969)

ウレアーゼ欠除クロレラ (Chlorella vulgaris Beijerinck var. viridis (chodat)) 細胞の尿素代謝を研 究した。 urea ${ }^{-14} \mathrm{C}$ のアルコール可溶画分への取込み は $10 \% \mathrm{CO}_{2}$ 含有空気中で消滅した。同様の結果はオ ルニチンとグルコース添加によって示された。尿素代 謝の初期生成物である種々のカルハミミル化合物はほと んど標識されなかった。また $10 \mathrm{~m} M \mathrm{KCN}$ 処理によっ て, 吸収された尿素チッ素の $1 / 2$ 以上が $\mathrm{NH}_{4}^{+}$として培 地から検出された。暗所, $\mathrm{N}_{2}$ ガス下の細胞は尿素ま たはアンモニアを吸収することができなかったが，光 照明によって吸収速度は正常に回復した。

（武長）

\section{4 種子における ${ }^{14} \mathrm{C}$-maltose の代謝}

Metabolism of ${ }^{14} \mathrm{C}$-Maltose in Avena fatua Seeds during Germination

S.S.C. Chen, J.E. Varner: MSU/AEC Plant Res. Lab., Michigan State Univ., East Lansing, Mich., Plant Physiol., 44, (5) 770 4 (1969)

収穫後, 室温で後熟させた野生カラスムギ (Avena fatua) 種子 (非休眠) 々 $-15^{\circ} \mathrm{C} て ゙$ 眝蔵した休眠種子 の発芽時における ${ }^{14} \mathrm{C}-\mathrm{U}$-maltose の代謝を比較検討 した。非休眠種子では胚乳部に供与した ${ }^{14} \mathrm{C}$-maltose は速やかに胚盤で ${ }^{14} \mathrm{C}$-sucrose に変化し, 胚へ移行し た。他方, 休眠種子では少量のsucrose ${ }^{3}{ }^{14} \mathrm{C}$-maltose から生成され, 胚乳中に maltose および glucose の 形態で蓄積される傾向が示された。以上の結果から, 種子発芽において胚乳貯蔵養分の胚への移行が勃果的 になされるためには sucrose の生合成が必要であると 考えた。

\section{5 セレン酸塩，垔セレン酸塩の移行}

Transport of Selenate and Selenite into Astragalus Roots

A. Shrift, J.M. Ulrich: Biol. Dept., State Univ. of New York, Binghamton, New York, Plant Physiol., 44, (6) 893 6 (1969)

レンゲのセレン蓄積種 (Astagalus crotalariae) と 非蓄積種 (A. lentiginosus) の切断根を $0.01 \mu \mathrm{M} / \mathrm{m} l$ $\mathrm{K}_{2}^{75} \mathrm{SeO}_{4}$ 溶液に 1 時間培養した。両品種とも添加濃度

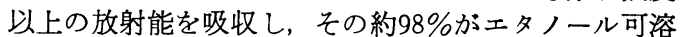
で，セレン酸塩の形態で積極的に移行することが証明 された。 $\mathrm{K}_{2}^{75} \mathrm{SeO}_{3}$ を同様に切断根に供与した場合, 吸 収量はかなり少量で, エタノール可溶放射能の量も添 加亜セレン酸濃度を越えることはなく, 相当量がエタ ノール不溶であった。両種について可溶性放射能を分 析した結果, 亜セレン酸塩の他の形態への変化が示さ れた。

\section{6 トゥモロコシ根の P 吸収と ATP 標識}

Oligomycin Inhibition of Phosphate Uptake and ATP Labelling in Excised Maize Roots

C. Bledsoe, C.V. Cole, C. Ross: Phosphorus Lab., Soil and Water Conservation Res. Div., ARSUSDA, Plant Physiol., 44, (7) 1040 4 (1969)

$20 \mu \mathrm{g} / \mathrm{ml}$ のオリゴマイシンを含む $5 \times 10^{-5} \mathrm{M} \mathrm{KH}_{2}$ ${ }^{32} \mathrm{PO}_{4}$ 溶液にトゥモロコシ切断根を 4 分間培養した結 果，リン酸吸収には影響はないが ${ }^{32} \mathrm{P}$ の ATP への 取込みは $34 \%$ 減少した。しかし切断根を長時間オリゴ マイシンで前処理または同時処理することによってリ ン酸吸収は減少し, ATP 生成は著しく減少した。切 断根に扔いて，オリゴマイシンはミトコンドリヤに拉 ける ATP 生成を阻害すること, ATP はプラズマレ ムマに括けるリン酸吸収のためのエネルギー源であ り, ATP の供給阻害がリン酸吸收を隇少させる要因 であることが示された。

(武長)

\section{7 根中におけるイオンの放射移動}

Radial Transport of Ions in Roots

G. Hu Yu, P.J.Kramer: Duke Univ., Durham, North Carolina: Plant Physiol., 44, (8) 1095 100 (1969)

発芽 4 日，7日目のトウモロコシ根および切断根を 用いて ${ }^{86} \mathrm{Rb},{ }^{36} \mathrm{Cl} .{ }^{32} \mathrm{P}$ の皮層, 中心柱への蓄積量を比 較した。 ${ }^{86} \mathrm{Rb}$ は $4 ， 7$ 日目とも中心柱に多量蓄積し た。 ${ }^{36} \mathrm{Cl}$ は両組織に同量蓄積したが，地上部を付け た根では23時間後には皮層に多く蓄積した。 ${ }^{32} \mathrm{P}$ は 1 時間の吸収では中心柱よりも皮層が大であったが，8 〜24時間後は差異がなかった。導管溢泌液中の ${ }^{86} \mathrm{Rb}$, ${ }^{36} \mathrm{Cl},{ }^{32} \mathrm{P}$ の含有量は中心柱と皮層への各イオンの蓄積 量の増加に伴って増加した。以上の結果からトウモロ コシ根のイオン蓄積能力は中心柱と皮層との間に差異 のないことが示された。 (武長)

\section{Kinetine ${ }^{-14} \mathbf{C}$, Adenine $\mathbf{- ~}^{14} \mathbf{C}$ の移動と代謝}

Movement and Metabolism of Kinetine ${ }^{-14} \mathrm{C}$ and of Adenine ${ }^{-14} \mathrm{C}$ in Coleus Petiole Segments of Increasing Age

H. Veen, W.P. Jacobs: Dept. of Biol., Princeton Univ., Princeton, New Jersey,Plant Physiol., 44, (9) $1277 \sim 84$ (1969)

生長期のコリウス葉柄の $5 \mathrm{~mm}$ 切片の基部または頂 部に adenine $-8{ }^{-14} \mathrm{C}$ または kinetine $-8{ }^{-14} \mathrm{C}$ 含有寒天 片を乗せ，移動を調べた。両化合物とる極方移動はみ られず, kinetine ${ }^{-14} \mathrm{C}$ は24時間まで順次移動量が増加 し, adenine ${ }^{-14} \mathrm{C}$ は 8 時間以後減少した。 kinetine${ }^{14} \mathrm{C}$ の移動は若い葉柄より老葉柄で大であった。また 24 時間後に kinetine ${ }^{-14} \mathrm{C}$ 処理の受容寒天片を調べた 結果, kinetine $\mathrm{e}^{-14} \mathrm{C}$ として検出され, adenine ${ }^{-14} \mathrm{C} て ゙$ は 6 時間後の受容寒天片中に adenine $\mathrm{e}^{-14} \mathrm{C}$ 以外に少 量の他化合物が検出された。24時間後に葉柄中の放射 能を調べた結果，両化合物とも約 $80 \%$ が代謝されてい た。 
4869 IAA 先駆体としてのトリフトトファン

Tryptophan as an Auxin Precursor in Cucumber Seedlings.

J.E. Sherwin, W.K. Purves: Dept. of Biol. Sci., Univ. of Calif., Santa Barbara, Plant Physiol., 44. (9) 1303〜9 (1969)

無菌または通常条件下で発芽，生育させたキュウリ 胚軸をトリプトファン-3- ${ }^{-14} \mathrm{C}$ 液中に培養したのち, 組織抽出液を薄層クロマトで分画した結果, 両条件の 胚軸ともトリプトファン- ${ }^{14} \mathrm{C}$ はインドール 酢酸 ${ }^{-14} \mathrm{C}$ $\left(\mathrm{IAA}-{ }^{14} \mathrm{C}\right)$ に変化することが示された。胚軸の伸長 る両条件でほとんど同じであった。これはキュウリ組 織に怙いてトリプトファンが IAA の先駆体であると いう仮説と一致するものである。トリプタミン $-2-{ }^{14} \mathrm{C}$, インドールェタノール $-{ }^{14} \mathrm{C}$ の $\mathrm{IAA}-{ }^{14} \mathrm{C}$ への変化\&両 条件下の胚軸で生じ，また胚軸の伸長も無菌条件でい ずれも減少しなかった。

\section{0 ピクロラムの移行, 分布}

Translocation and Distribution of Picloram in Bean Plants Associated with Nastic Movements

C.P.P. Reid, W. Hurtt: Plant Sci. Lab., Fort Detrick, Frederick, Maryland, Plant Physiol., 44, (10) 1393 6 (1969)

インゲン豆幼植物に ${ }^{14} \mathrm{C}$ 標識ピクロラム (4-amino3, 5,6-trichloropicolinic acid) を供与し，3，6,11時 間経根吸収させたのち, 植物の 10 部位について ${ }^{14} \mathrm{C}$ 含 有量を測定した。各部位の ${ }^{14} \mathrm{C}$ 蓄積量は処理時間とと るに増加した。3 時間処理で, 新鮮重 $1 \mathrm{mg}$ あたり 0.3 (節間) 1.065(頂芽) ng のピクロラム蓄積により荃 の50〜60 mm の位置が垂直に対して60〜80度わん曲し た。処理 6 時間後に新鮮重 $1 \mathrm{mg}$ あたり葉中に 0.803 $\sim 0.85 \mathrm{ng}$ 蓄積し，本葉の下偏生長が示された。根部 から地上部へのピクロラムの移行は非常に速く, 頂芽 と第一本葉に選択的に蓄積した。

(武長)

\section{1 ナンキンマメ幼植物の C-6989 代謝}

Movement and Fate of $p$-Nitrophenyl- $\alpha, \alpha, \alpha-$ Trifluoro-2-Nitro- $p$-Tolyl Ether $-1^{\prime}-{ }^{14} \mathrm{C}$ in Peanut Seedlings

E.F.Eastin: Soil and Crop Sci. Dept., Texas A \&M Univ., College Station, Texas, Plant Physiol., 44, (10) 1397〜401 (1969)

ナソキンマメ幼植物は $p$-nitrophenyl- $\alpha, \alpha, \alpha$-trifluoro-2-nitro- $p$-tolyl ether $-1^{\prime-14} \mathrm{C}(\mathrm{C}$-5939) を速や かに経根吸収したが，地上部への移行は微量であっ た。（C-6989）代謝の主経路はエーテル結合の加水分 解と 4-nitrophenol(I) の還元による 4-aminophenol （II）の生成であった。(II)，（C-6989），（I）の放射能 分布率は48時間後が67.8,17.4,13.5\%,144時間後では 64. 3, 4.0,0.9\%であった。また少量のp-nitrophenyl$\alpha, \alpha, \alpha$-trifluoro-2-amino- $p$-tolyl ether $<p$-aminophenyl- $\alpha, \alpha, \alpha$-trifluoro-2-nitro- $p$-tolyl ether が検 出されたが, $p$-aminophenyl- $\alpha, \alpha, \alpha$-trifluoro-2amino-p-tolyl ether は検出されなかった。（武長）

\section{2 単離した葉細胞による鉄吸収}

Factors Related to Iron Absorption by Enzymically Isolated Leaf Cells

S. Kannan: Dept. of Horticul., Michigan State Univ., East Lansing, Mich., Plant Physiol., 44, (10) $1457 \sim 60$ (1969)

タバコ葉の細胞を酵素作用によって単離 し, ショ 糖, tris-maleate ( $\mathrm{pH}$ 6.4) および ${ }^{59} \mathrm{FeSO}_{4}$ または ${ }^{54} \mathrm{MnSO}_{4}$ を含む培地に培養した。若い葉から得た細 胞の ${ }^{59} \mathrm{Fe}$ 吸収速度は老葉細胞のものよりも大であっ た。また培地への $\mathrm{CaSO}_{4}$ 添加によって ${ }^{59} \mathrm{Fe},{ }^{54} \mathrm{Mn}$ 吸 収は阻害された。葉細胞の $\mathrm{Fe}$ および $\mathrm{Mn}$ 吸収にお。 いて相互に拮抗的であったが， $\mathrm{Ca}$ は Fe による $\mathrm{Mn}$ 吸收阻害を増進し，逆に Mn による Fe 吸収阻害を 軽減した。タバコ葉細胞の $\mathrm{Fe}$ 吸収に対する親和定数 は低く，また $0.1 \mathrm{~m} M$ EDDHA の添加によって Fe 吸収は完全に阻害された。

(武長)

\section{$4873{ }^{32} \mathbf{P}$ の吸収, 移動と Decenylsuccinic acid}

Effects of Decenylsuccinic Acid on ${ }^{32} \mathrm{P}$ Uptake and Translocation by Barley and Winter Wheat

D.G. Green, W.S. Ferguson, F.G. Warder: Res. Station, Res. Branch, Canada Agr., Swift Current, Saskatchewan, Plant Physiol., 45, (1) 1 3 (1970)

冬小麦を $10^{-3} \sim 10^{-4} M$ decenylsuccinic acid (DSA) を含む水耕液で培養した結果，3 日後に青枮れ症状を 呈し，枮死した。また $10^{-3} M \mathrm{DSA}$ は大麦，冬小麦 の ${ }^{32} \mathrm{P}$ 経根吸収を阻害し，かつあらかじめ吸収してい た ${ }^{32} \mathrm{P}$ 打よび体内リン酸の相当量を培地に溶出した。 ${ }^{32} \mathrm{P}$ の吸収と体内保持に打よぼす DSA の作用は根の 損傷から生じた透過性の増大に起因するすのと考えら れた。 $10^{-4} M$ DSA は ${ }^{32} \mathrm{P}$ 吸収を阻害しないが地上部 への移行を減少させた。これは蒸散作用の減退と ${ }^{32} \mathrm{P}$ の蒸散流への取込み阻害によるものと考えられた。 DSA は冬小麦の耐寒性を増加しなかった。（武長）

\section{4 核酸合成への Gibberellin, Abscisic acid の影響}

Regulation of Bud Rest in Tubers of Potato, Solanum tuberosum L. VII. Effect of Abscisic and Gibberellic Acids on Nucleic Acid Synthesis in Excised Buds

C.Y.Shih, L. Rappaport: Dept. of Vegetable Crops, Univ. of Calif., Davis, Calif., Plant Phy. siol., 45, (1) 33〜36 (1970)

${ }^{3} \mathrm{H}$-チミジンまたは ${ }^{3} \mathrm{H}$ ーウリシンン $10^{-4} M$ Gibberellin $\mathrm{A}_{3}\left(\mathrm{GA}_{3}\right)$ および abscisic acid (ABA) を別 個にまたは混合して加えた各供試液でジャガイモ塊茎 の頂芽を 3 日間処理したのち頂芽を切り取り,さらに 12時間処理を継続して頂芽の DNA および RNA へ の ${ }^{3} \mathrm{H}$ の取込みに対する影響を調べた。また別に，あ らかじめ頂芽を分離したのち各供試液で12時間処理し た。その結果, 処理時間の長さにかかわりなく, $\mathrm{GA}_{3}$ は DNA および RNA への ${ }^{3} \mathrm{H}$ の取込みをわずかに 促進した。一方, $\mathrm{ABA}$ は $\mathrm{GA}_{3}$ の存在いかんに関係 なく, ${ }^{3} \mathrm{H}$ の取込みを阻害した。
(武長) 


\section{5 t-RNA の結合因子}

A Factor for the Binding of Aminoacyl Transfer RNA to Mammalian 40S Ribosomal Subunits

D.P. Leader, I.G. Wool, J. J. Castles: Dept. of Physiol., Biochem., and Med., Univ. of Chicago, Chicago, Proc. Natl. Acad. Sci. USA, 67, (2) 523 8 (1970)

$\mathrm{K}^{+}$, GTP, Poly U存在下にラット骨格筋の40Sリボ ゾーム亜粒子への ${ }^{3} \mathrm{H}-\mathrm{Ph}$ - $-\mathrm{RNA}$ の結合を, $\mathrm{Mg}^{2+}$ 濃 度拁よびラット肝上澄み由来のアミノアシルトランス フェーラーゼ I (T-1) の精製段階を変えて加えて調べ ると T-1精製の初期段階の抽出液中に, 低濃度の $\mathrm{Mg}^{2+}$ のもとで Phe-tRNA の 40S 亜粒子への結合を促進 する因子が存在することがわかった。T-1とはカラム での挙動, 低濃度 $\mathrm{Mg}^{2+}$ 下での促進, GTP への依存, 耐熱性の弱いこと, NEM で不活性化される点で, T-2 とは, Phe-tRNA の 40S 亜粒子への結合に働く という点で区別される新しい因子である。

(西川)
4876 ベブチド鎖終了後の解離反応について

Peptide Chain Termination: Effect of Protein S on Ribosomal Binding of Release Factors

J.L. Goldstein, C.T. Caskey: Sect. of Med. Genet., Lab. of Biochem. Genet., Natl. Heart and Lung Inst., Proc. Natl. Acad. Sci. USA, 67, (2) $537 \sim 43$ (1970)

リボゾーム, UAA, R 因子, エタノール存在下に $\mathrm{S}$ 因子は[R・UAA・リボゾーム] 中間体の形成を促 進し,ここに GTP, GDP が存在すると S 因子は, この中間体の解離に働く。UAA のリボゾームへの結 合は ${ }^{3} \mathrm{H}-\mathrm{UAA}$ を用いてフィルター法で測定し, R 因 子のリボゾームへの結合は〔 $\mathrm{f}^{3} \mathrm{H}-\mathrm{Met}$ tRNAf・AUG・ リボゾーム】中間体, UAA, GTP の存在下に, その リボゾーム (R因子結合) を加えて解離してくる $\mathrm{f}^{3} \mathrm{H}-$ Met のカウントで测定した。さらに GTPを添加し ようとしまいと S 因子は[fMet tRNAf・AUG・リボゾ 一ム」中間体からの R⿴囗大源による $\mathrm{fMet}$ の解離を促進 した。

(西川)

\section{7 脳ポリソームからの mRNA}

Isolation of RNA with Properties of Messenger RNA from Cerebral Polyribosomes

C.E. Zomzely, S. Roberts, S. Reache: Dept. of Biol. Chem., School of Med., and Brain Res. Inst., Univ. of Calif. Center for Health Sci., Proc. Natl. Acad. Sci. USA, 67, (2) 644〜51 (1970)

成長したラットの大脳皮質のポリゾームを EDTA 処理し解離してきた RNA の性質を調べた。この RNA は全ポリゾーム RNA の $2 \%$ 量を占め, 塩基組 成拉よびハイブリダイゼーションの点で rRNA や tRNA とは異なり，より DNA に近かった。またこ の RNA は, 洗ったリボゾームに $\mathrm{pH} 5$ フラクション

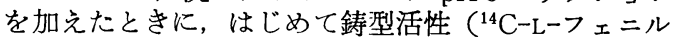
アラニンの TCA 不溶性画分への取込みで測定) を示 した。また沈降分析の結果 $8 \mathrm{~S}$ と $16 \mathrm{~S}$ のつのピー クよりなっていた。以上の結果からこの RNA はメッ センジャー RNA であることがわかった。

(西川)

\section{8 トルエン処理菌の DNA 複製と修復}

Replication and Repair of DNA in Cells of Escherichia coli Treated with Toluene

R.E. Moses, C.C. Richardson: Dept. of Biol. Chem., Harvard Med. School, Boston, Mass., Proc. Natl. Acad. Sci. USA, 67, (2) 674 81 (1970)

トルエン処理した E. coli では $\mathrm{Mg}^{2+}, \mathrm{K}^{+}, \mathrm{ATP}$, dXTP 存在下 $に$ DNA 合成 $\left(\alpha-{ }^{32} \mathrm{P}-\mathrm{dTTP}, \alpha-{ }^{32} \mathrm{P}-\right.$ $\mathrm{dATP},{ }^{3} \mathrm{H}-\mathrm{dATP},{ }^{3} \mathrm{H}-\mathrm{dCTP}$ の酸不溶性画分への取 りこみで测定）が起こる。この DNA 合成は end Iの菌, Pol Al- の菌でも起こり, in vivo と同じ速度 で進行し，トルェン処理前にラベルして扣いた DNA にラベルの dXTP が取りこまれ，半保存的に進行し， ATP を要求し, DNase では促進されず, NEM で阻 害されるなどの点で, EDTA 処理したE. coliでの 修復の DNA 合成とは違った複製の DNA 合成であ ると思われる。

(西川)

\section{T4 によるタンパク合成開始の阻害}

The Selective Inhibition of Protein Initiation by T4 phage-Induced Factors

E.B.Klem, W.T.Hsu, S.B. Weiss: Dept. of Biochem., Univ. of Chicago and Argonne Cancer Res. Hosp., Chicago, Proc. Natl. Acad. Sci. USA, 67, (2) $696 \sim 701$ (1970)

${ }^{3} \mathrm{H}$-ラベルの E. coli, T4, T5, MS2RNA それぞれ の washed E. coli リボゾームへの結合を E. coli の fMet tRNAf そしてE. coli あるいは T4 感染菌のリ ボゾーム洗液（因子）を加えて調べると MS2，E. coli RNA の結合がT4 の因子によって阻害された。また 各 RNA, washed リボゾーム, GTP, $\mathrm{Mg}^{2+}$ の存在下 にE. coli あるいはT4の因子を加えフィルター法で ${ }^{3} \mathrm{H}$ fMet-tRNAf のリボゾームへの結合を調べるとMS2, E. coli RNA の結合が T4 の因子によって阻害され た。T4の因子はペプチド鎖の伸長のほうには影響し なかった。T4 因子は MS2, E. coli RNA をテンプレ 一トとしたときにイニシェーションコンプレックスの 形成を阻害していることがわかった。（西川）

\section{DNA 温度感受性変異株}

On the Process of Cellular Division in Escherichia coli, V. Incorporation of Deoxynucleoside Triphosphates by DNA Thermosensitive Mutants of Escherichia coli also Lacking DNA Polymerase Activity

J. Mordoh, Y. Hirota, F. Jacob: Service de Génétique Cellulaire de L'institute Pasteur et du Collige de France, Paris, Proc. Natl. Acad. Sci. USA, 67, (2) 773 8 (1970)

Cairus の変異株から P1 形質導入とクロスにより DnaA-PolA1- 株, DnaB-PolA1- 株を得た。この両

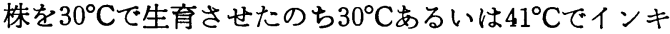
ユベートしさらに $1 \%$ トルェン処理し $\mathrm{Mg}^{2+}$, ATP, $\mathrm{KCl}, \mathrm{dXTP}$ の存在下に ${ }^{3} \mathrm{H}-\mathrm{dATP}$ の DNA への 取りこみを $30^{\circ} \mathrm{C}, 41^{\circ} \mathrm{C} て ゙$ 調べた。その結果 $\mathrm{DnaB}^{-}$ PolA1- 株では $41^{\circ} \mathrm{C}-ト ル エ ン ー 41^{\circ} \mathrm{C}$ 系で取込みが完 全に抑えられ, DnaA-PolA1- 株では $41^{\circ} \mathrm{C}$ ートルエンー $41^{\circ} \mathrm{C}$ 系で取込みが完全に抑えられ $30^{\circ} \mathrm{C}$ ートルエンー41 ○の系では取こみが途中で停止した。（西川） 
4881 シュードウリジンの生合成

In vitro Biosynthesis of Pseudouridine at the Polynucleotide Level by an Enzyme Extract from Escherichia coli

L. Johnson, D. Söll: Dept. of Mol. Biophys. and Biochem., Yale Univ., New Haven, Conn., Proc. Natl. Acad. Sci. USA, 67, (2) 943 50 (1970)

Mycoplasm sp. Kid の DNA は tRNA 遺伝子を 多く含み E. coli RNA ポリメラーゼで transcribeさ れる。 ${ }^{14} \mathrm{C}$ ーウリジンでラベルした RNA プロダクトを E. coli 細胞抽出液とインキュベートしヌクレオチド 分析を行な 5 と ${ }^{14} \mathrm{C}$ ーシュードウリジンができていた。 このことからウリジンからシュードウリジンへの変化 は高分子レベルで起こるという説が支持される。さら にこの変化は ${ }^{14} \mathrm{C}$ ーポリUや ${ }^{14} \mathrm{C}$ ーウリジンラベルした $\lambda$ の RNA には起こらぬことから RNA 様物質のウ リジン残基に特有の反応であると思われる。

(西川)

\section{2 核小体の rRNA 先駆体}

Sites of Synthesis and Processing of Ribosomal RNA Precursors within the Nucleolus of Urechis caupo Eggs

N.K. Das, J. Micou-Eastwood, G. Ramamurty, M. Alfert: Dept. of Zool., Univ. of Calif., Berkeley, Calif., Proc. Natl. Acad. Sci. USA, 67, (2) 968〜 75 (1970)

ウニの未受精卵を 5-3 H-ウリジンを含む海水中で適 当時間標識したのち，コールドのウリジンとアクチノ マイシンDでのちの合成を抑えつつインキュベートし てから核小体を分離しオートラジオグラムをとると時 間の経過とともに core で合成された RNA が cortex に移動していることがわかる。これと平行に核小体か ら RNA を抽出しショ糖密度勾配遠心分析にかけると core で合成された RNA は 38S, cortex に移った RNA は $30 \mathrm{~S}$ の大きさであった。このことから $38 \mathrm{~S}$ RNA の最初の切断は core のところで起こるすのと 思われる。

(西川)

\section{RNA 依存の DNA 合成}

DNA Synthesis by RNA-Containing Tumor Viruses

E.M. Scolnick, S.A. Aaronson, G. J. Todaro: Viral Carcinogenesis Branch, Natl. Cancer Inst., Bethesda, Md., Proc. Natl. Acad. Sci. USA, 67, (2) 1034 $\sim 41$ (1970)

ネズミの白血病ウイルス, 肉腫ウイルス粒子にRNA 依存 DNA ポリメラーゼが存在する。活性の検出はウ イルス・サスペンジョンに $\mathrm{Mg}^{2+}$, dithiothreitol $\mathrm{NaCl}$, $\mathrm{dXTP}$, さらに $0.01 \%(\mathrm{v} / \mathrm{v})$ Triton X-100を加え ${ }^{3} \mathrm{H}-\mathrm{dTTP}$ の酸不溶性画分への取込みでチェックし た。反応の至適温度は $37^{\circ} \mathrm{C}$ 。Triton X-100 がないと ほとんど活性はない。本酵素はビリオン $\left({ }^{14} \mathrm{C}\right.$-ラベル の対照) そして反応生産物である DNA と共沈する。 また本酵素はC 型の白血病, 肉腫 RNA ウイルス, B 型ウイルスのような発ガン性ウイルスにのみみられ, 非発ガン性ウイルスにはみられない。

(西川)

\section{4 in vitro の DNA 依存 RNA directed タンパク合成系}

DNA-dependent RNA-directed Protein Synthesis in vitro, $\mathbb{I}$ Peptide Analysis of an in vitro and in vivo $\phi \times 174$ Stractural Protein

D. H. Gelfand, M. Hayashi: Dept. of Biol., Univ of Calif., San Diego, Proc. Natl. Acad. Sci. USA, 67, (1) 13〜17 (1970)

E. coli に $\phi \times 174$ を感染させたの ち ${ }^{3} \mathrm{H}$-arginine, ${ }^{3} \mathrm{H}$-lysine を加えて ${ }^{3} \mathrm{H}-\phi \times 174$ を調製しフェノール処 理後アクリルアミドゲル電気泳動にて“spike” protein のフラクションを集める。一方， $\phi \times 174$ の RF-DNA, RNA ポリメラーゼ, ${ }^{14} \mathrm{C}$-arginine, ${ }^{14} \mathrm{C}$-lysine を含 むDNA 依存の RNA directed protein synthesis system で合成させたタンパクを $\phi \times 174$ 抗血清沈殿 性画分のみを同電気泳動にて分画する。この両者を卜 リプシン処理し, ペプチドクロマトグラフィにかけた 結果，基本的に同様のパターンを示した。

(西川)

\section{5 高等動物でのペプチド鎖の終了，解離}

Peptide Chain Termination with Mammalian Release Factor

J.L. Goldstein, A.L. Beaudet, C.T. Caskey: Sec. of Med. Genet., Lab. of Biochem. Genet., Natl. Heart and Lung Inst., NIH, Bethesda, Proc. Natl. Acad. Sci. USA, 67, (1) 99 (1970)

$55 \mathrm{~m} M \mathrm{Mg}^{2+}$ 存在下に E. coli 女るいは家鬼の $\mathrm{f}\left[{ }^{3} \mathrm{H}\right]$-Met-tRNAf は, テンプレートなしに家兔網状 赤血球のリボゾームの initiator (P) サイトに結合し た。この結合した $\mathrm{f}\left[{ }^{3} \mathrm{H}\right]-\mathrm{Met}$ の解離にはポリ UA, それに家兔網状赤血球ライガートの S 105 フラクショ ンに含まれるR因子を必要とし，さらに GTP は促進 作用をすつ。この $\mathrm{R}$ 因子は $55^{\circ} \mathrm{C} 10$ 分処理, フェノール 処理, NEM 処理すると不活性化する。そしてまたこ のR因子は E. coli のリボゾームの系には無効であっ た。ペプチジル・トランスフェラーゼ活性を阻害する スパルソマイシン, ゴウゲロチンは解離反応を阻害し た。 (西川)

\section{RNA ウィルスに結合した DNA ポリメ ラーゼ}

DNA Polymerase Activity Associated with RNA Tumor Viruses

M. Hatanaka, R.J. Huebner, R.V. Gildent: Flow Lab., Inc., Rockville, Maryland, Proc. Natl. Acad. Sci. USA, 67, (1) 143 7 (1970)

マウス，ハムスター，ネコ，マムシのC型 RNA ウ イルスからビリオンに結合した DNA ポリメラーゼ活 性を検出した。活性の測定は，ウイルス・サスペンジ ョンに, $\mathrm{Mg}^{2+}$, dithiothreitol, dXTP を加え, ${ }^{3} \mathrm{H}-$ dTTP の $10 \%$ TCA 不溶性画分への取込みでチェック した。反応の速度およびレベルは，エーテルの添加に よってかなり促進された。合成されたDNAは, intact virus をテンプレートとして使用した場合，ビリオン と結合していた（エーテル処理したウイルスを使用し た場合にはそのようなことはなかった)。合成された DNA は，抽出し分析した結果 2〜4S であった。 


\section{DNA 合成の開始}

Control of Initiation of DNA Synthesis in Escherichia coli $\mathrm{B} / \mathrm{r}$

C.B. Ward, D.A. Glaser: Virus Lab., Univ. of Calif., Berkeley, Proc. Natl. Acad. Sci. USA, 67, (1) $255 \sim 62$ (1970)

同調培養させた $E$. coli $\mathrm{B} / \mathrm{r}$ チミン要求株を 5 分間 ${ }^{3} \mathrm{H}$-チミンでパルスラベルし 35 分間チェイスして一回 りさせたのち, DNA 合成阻害剤の nalidixic acid を 45分間処理し，つぎにチミンのかわりに5-ブロモウラ シルを含む培地に移し適時サンプリングし， DNA を 抽出し, $\mathrm{CsCl}$ 密度勾配遠心分析し，ハイブリッド $\left({ }^{3} \mathrm{H}\right.$ ラベル打よび5ーブロモウラシル）の部分の出現する時 間を調べた結果, nalidixic acid を除去したあとに起 こる premature reinitiation のために nalidixic acid 処理前に進行していた DNA 合成の続行が抑えられ ることがわかった。

(西川)

\section{ATP 依存のエンドヌクレアーゼ}

An Endonuclease Activity from Escherichia coli Absent from Certain $\mathrm{rec}^{-}$Strains

P. J. Goldmark, S. Linn: Dept. of Biochem. and Mol. Biol., Univ. of Calif., Barkeley, Calif., Proc. Natl. Acad. Sci. USA, 67, (1) 434 41 (1970) 本酵素を一本鎖環状の $\left[{ }^{3} \mathrm{H}\right] \mathrm{fdDNA}$ が exonuclease I (E. coli) 感受性に変化する活性でチェックしつつ精 製した。本酵素は分子量30万, 活性には $\mathrm{Mg}^{2+}$, ATP を要求し, 至適 $\mathrm{pH}$ は6.5〜8.2であった。そして無機 リンによって阻害を受け，カフェイン(暗回復阻害剂) や tRNA (endonuclease I) には影響されなかった。 さらに本酵素活性は rec B-, rec $\mathrm{C}^{-}$両変異株には検 出されず, かえって両株には rec $\mathrm{A}^{-}, \operatorname{rec} \mathrm{A}^{+}$両株 の すつ本䤉素活性を阻害するすのが含まれていることが わかった。以上のことから本酥素は組み換えの過程で 働くものと思われる。

(西川)

\section{1 ファージ进伝子由来の tRNA}

Detection of Bacteriophage T4- and T5-coded Transfer RNAs

N.H. Scherberg, S.B. Weiss: Dept. of Biochem., Univ. of Chicago, and Argonne Cancer Res. Hosp., Chicago, Ill., Proc. Natl. Acad. Sci. USA, 67, (3) $1164 \sim 71$ (1970)

T4 ファージ感染菌から tRNA を抽出し ${ }^{3} \mathrm{H}-\mathrm{L}-ア$

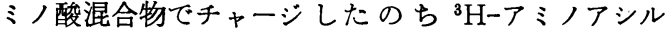
tRNAs を分離する。これを T4 DNA フィルターと

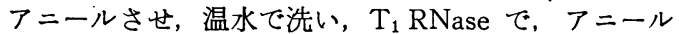
したラベルを水層に回収して調べた結果, アルギニン, プロリン，グリシン，イソロイシン，そしてロイシン

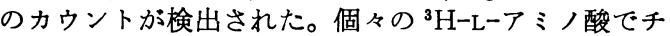
ャージさせた tRNA を使い, 上記の方法で調べても 同様の結果が出た。さらに T4 ファージ感染菌からの tRNA をT4 DNA とアニールした分のみ分離して個 々の ${ }^{3} \mathrm{H}-\mathrm{L}$ ーアミノ酸のチャージングを行なわせてる上 記のアミノ酸のみが特異的にチャージされた。T5 ᄀ アージ感染菌についても調べられた。 (西川)
4888 RNA ウィルスに結合した DNA ポリメ ラーセ

Mechanism of Carcinogenesis by RNA Tumor Viruses, I. An RNA-Dependent DNA Polymerase in Murine Sarcoma Viruses

M. Green, et al.: Inst. for Mol. Virol., Saint Louis Univ. School of Med., Saint Louis, Proc. Natl. Acad. Sci. USA, 67, (1) 385 93 (1970)

ネズミ肉腫 virus 粒子に RNA 依存 DNA ポリメ ラーゼ活性を検出した。活性の測定はウイルスサスペ ンジョンに $\mathrm{Mg}^{2+}$, dithiothreitol, dXTP, さらに0.01 \% Nonidet P-40 を加え, ${ }^{3} \mathrm{H}-\mathrm{dTTP}$ の PCA 不溶性 画分へのとりこみで行なった。反応はウイルス粒子の 濃度に比例し，4 dXTP および $\mathrm{Mg}^{2+}$ (または $\mathrm{Mn}^{2+}$ ) は不可欠で， $0.01 \%$ の種々の非イオン系界面活性剤の 添加効果は, 無添加の場合の15倍以上に拉よび, 至適

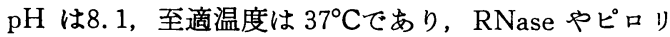
ン酸によって阻害をうける。できたDNAの大きさは

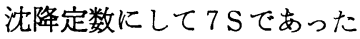

(西川)

$4890 \boldsymbol{E}$. coli の新しいタンパク合成因子 $\mathbf{F}_{\mathrm{AB}}$

A New Protein Synthesis Factor from Escheri. chia coli

Y.W. Kan, F. Golini, R.E. Thach: Div. of Hematol., Dept. of Pediatrics, Children's Hospital Med. Center and Harvard Med. School, Boston, Proc. Natl. Acad. Sci. USA, 67, (3) 1137 42 (1970)

Poly U. $7.5 \mathrm{mM} \mathrm{Mg}{ }^{2+}$ 存在下に ${ }^{3} \mathrm{H}-\mathrm{Phe}-\mathrm{t}$ RNA の E. coli 30 S リボゾーム亜粒子への結合をメンブランフ ィルター法で測定したさい, リボゾームの $1 M \mathrm{NH}_{4} \mathrm{Cl}$ 洗液中に, 結合を促進する因子 $\left(\mathrm{F}_{\mathrm{AB}}\right)$ を見つけた。 この結合は開始因子 $F_{1}$ や GTP で阻害され，70Sリ ボゾームへのアミノアシル tRNA の結合に働く T因 子，それに $\mathrm{G}$ 因子には影響されない。またここの因子 は AUG, $7.5 \mathrm{mM} \mathrm{Mg} \mathrm{Mg}^{2+}, \mathrm{F}_{1}$ 因子, GTP 存在下の $\mathrm{f}-{ }^{14} \mathrm{C}-\mathrm{Met}-\mathrm{t} R \mathrm{NA}$ の $30 \mathrm{~S}$ リボゾーム亜粒子の結合に は働かないが, 30S+50S リボゾームの系でのポリフ エニルアラニン合成を促進することなどがわかった。 (西川)

4892 Q $\beta$ RNA上のコートタンパクシストロンの位置 Location of the Coat Cistron on the RNA of Phage $Q \beta$

J. Hindley, et al.: Dept. of Biochem., Univ. of Bristol, and Inst. für Molekularbiologie der Univ. Zürich, Proc. Natl. Acad. Sci. USA, 67, (3) 1180 7 (1970)

変性二本鎖 $\mathrm{Q} \beta \mathrm{RNA}, \mathrm{Q} \beta$ レプリカーゼ, $\mathrm{Mg}^{2+}$ 存在 下に $\alpha^{32} \mathrm{P}-\mathrm{GTP}$, コールドの ATP を加えてイニシェー ションを行なったのち，コールドの XTP を加えてェ ロンゲーションを行なわせ，さまざまの鎖長までラべ ルしたのちチェイスし，完全な鎖長のQ $\beta$ RNA(十鎖) を作る。その各 RNA をリボゾーム, f Met-tRNAf そしてGTP とインキュベートしてイニシェーション コンプレックスを形成 $(\mathrm{Q} \beta$ RNA の場合コートタン パクのイニシェーションサイトとのみ形成) させ, そ の膵臓 RNase 抵抗性の部分への ${ }^{32} \mathrm{P}$ の放射能の回収 の傾向を調べた結果5'末端から1400ヌクレオチド付近 にコートタンパクのイニシェーションサイトがあるこ とがわかった。 (西川) 


\section{3 脳と肝臓中の Ser-tRNA の違い}

Seryl-tRNA in Mammalian Tissues: Chromatographic Differences in Brain and Liver and a Specific Responce to the Codon, UGA

D. Hatfield, F.H. Portugal: Chem. Branch, Natl. Cancer Inst., and Lab. of Biochem. Genetics, Natl. Heart and Lung Inst., NIH, Bethesda, Md., Proc. Natl. Acad. Sci. USA, 67, (3) 1200 6 (1970)

ウシおよび家鬼の脳と肝臓中の tRNA（脱アシル化 処理をする)，アミノアシル tRNA 合成酵素を ATP, $\mathrm{Mg}^{2+}, 19$ 種のコールドのアミノ酸, ${ }^{14} \mathrm{C}-$ あるいは ${ }^{3} \mathrm{H}-$ セリンとインキュベートして Ser-tRNA をつくり逆 相クロマトにかけると, 脳と肝㵴の Ser-tRNA の溶 出のパターンがピークの数と位置の点で違う。この違 いは相互入換えの実験から tRNA に起因すると思わ れる。さらにコドン認識の実験からバクテリアの系で タンパク合成終了を告げるコドンUGAをウシ，家鬼 それにニワトリの Ser-tRNA の一種が認識すること がわかり，その tRNA の役割が注目される。

(西川)

\section{30S リボソームのトポグラフィ}

Topography of the Escherichia coli 30S Ribosomal Subunit and Streptomycin Binding

F.N. Chang, J.G. Flaks: Dept. of Biochem., School of Med., Univ. of Penn., Phil., Proc. Natl. Acad. Sci. USA, 67, (3) 1321 8 (1970)

E. coli Q13 (SM 感受性) から 30S リボゾーム亜 粒子を調製しトリプシン濃度を変えて処理する。処理

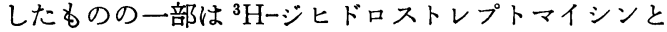
インキュベートしラベルの結合を調べ, 残りの部分は $4 M$ 塩化リチウム, $8 M$ 尿素処理しタンパク部分をポ リアクリルアミドゲル電気泳動にかけ比色でピークを 同定し，リボゾームタンパクの脱離を調べる。その結 果, トリプシン処理によるリボゾームタンパクの脱離 には順序性（それは，ほほ，再構成のアッセンブリー の順序と逆）があり, SM の結合は, 初めから $7 \sim 8$ 番目のタンパク (P8, P11) の脱離に影響されること がわかった。 (西川)

\section{4 葉緑体のアミノアシル tRNA 合成酵素}

Identification and Origin of Some Chloroplast Aminoacyl-tRNA Synthetases and tRNAs

B. J. Reger, et al.: Biol. Div., Oak Ridge Natl. Lab., Oak Ridge, Tenn., Proc. Natl. Acad. Sci. USA, 67, (3) $1207 \sim 13$ (1970)

明所と暗所で育てた野生株と明所で育てた葉緑体欠 の変異株のユーグレナの 3 者のIleu-tRNA synthetase 活性 (明所で生育した野生株の $\mathrm{tRNA} へ{ }^{14} \mathrm{C}-$ Ileu 結合する活性でチェック)を調べると DEAE では 3 者に共通のピークが 1 つ, そして明所で育てた野生株

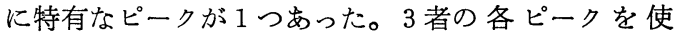
い, 朔相クロマトで分画した 3 者の tRNA をアシル 化する活性を調べると， 3 者に共通のピークの酵素は 3 者に共通の tRNA のみをアシル化し, 明所で育て た野性株に特有のピークの酵素は明所で育てた野生株 に特有の $\mathrm{t} R \mathrm{RA}$ のみを゙アシル化した。そして明所で 育てた野生株に特有の酵素, tRNA はともに葉緑体中 に存在することがわかった。Pheについても調べられ た。

(西川)

\section{30S リボソームのトポグラフィ}

Three-Dimensional Organization of the $30 \mathrm{~S} \mathrm{Ri}$ bosomal Proteins from Escherichia coli 1. Preliminary Classification of the Proteins

G.R. Craven, V. Gupta: Lab. of Mol. Biol., and Dept. of Genet., Univ. of Wisconsin, Madison, Wis., Proc. Natl. Acad. Sci. USA, 67, (3) 1329 〜36 (1970)

E. coli MRE から調製した 30S リボゾーム亜粒子 を ${ }^{14} \mathrm{C}$-ヨード酢酸 ( $\mathrm{SH}$ 試薬)，2ーメトキシー5ーニトロ トロポン（アミノ基と反応して発色）そしてトリプシ ンとそれぞれ別個に反応させたのち rRNA を除き $6 M$ 尿素処理してポリアクリルアミドゲル電気泳動あるい はリン酸セルローズクロマトにかけ, 各リボゾームタ ンパクへの結合怙よび各リボゾームタンパクの脱離を 調べ，その相関関係から11の外部タンパクと9の内部 タンパクに類別を試みた。そしてその類別が再構成了 ッセンブリーのパターンとも関係していることが示さ れた。

(西川)

\section{7 アセチル CoA カルボキシラーゼの解離}

Enzymatic Carboxylation of Biotin: Molecular and Catalytic Properties of a Component Enzyme of Acetyl CoA Carboxylase

P. Dimroth, R.B. Guchhait, E. Stall, M.D. Lane: Dept. of Physiol. Chem., Johns Hopkins Univ. School of Med., Baltimore, Md. Proc. Natl. Acad. Sci. USA, 67, (3) 1353 60 (1970)

対数増殖期の E. coli B からビオチンカルボキシラ 一ゼ (アセチル CoA カルボキシラーゼの成分)を ATP, d-ビオチン, $\mathrm{Mg}^{2+}$ 存在下に ${ }^{14} \mathrm{C}-\mathrm{KHCO}_{3}$ のカ ルボキシビオチン骨格への取込みでチェックしつつ, 硫安沈殿，リン酸カルシウムゲル，DEAE セルロー ズ, リン酸セルローズクロマトで2000倍にまで精製。 セファデックス G-200, SDS-ポリアクリルアミドゲ ル電気泳動での挙動から本酵素は分子量 5 万のサブュ ニット 2 つりなる分子量10万のタンパクであること がわかった。また本酵素活性は $15 \%(\mathrm{v} / \mathrm{v})$ のエタノ ールで15倍促進された。

\section{8 グルタミン合成酵素の制御}

Association of ATP: Glutamine Synthetase Adenyltransferase Activity with the $P_{1}$ Component of the Glutamine Synthetase Deadenylation System

W.B. Anderson, et al.: Lab. of Biochem. Natl. Heart and Lung Inst., Bethesda, Md., Proc. Natl. Acad. Sci. USA, 67, (3) 1417 24 (1970)

E. coli に打けるグルタミン合成醉素 (GS) 活性は グルタミンと $\alpha-\mathrm{KG}$ の濃度変化に応じた, 酵素のア デニル化, 脱アデニル化により制御されることが知ら れている。 $\mathrm{Mg}^{2+}$, グルタミン, アデニルトランスフ エラーゼ(A Tase)存在下に GS を ${ }^{14} \mathrm{C}-\mathrm{ATP}$ と反応

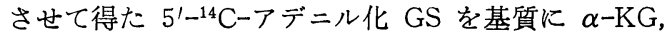
ATP, UTP 存在下に脱アデニル化活性を測定した。 その結果脱アデニル化活性はクロマトでさらに $\mathrm{P}_{I}, \mathrm{P}_{\text {II }}$ の成分に分けられたが， $P_{I}$ 成分はアガロースゲルロ 過, DE 32 七ルローズ, ハイドロキシアパタイドクロ マト, ディスクゲル電気泳動, 熱変性の点で A Tase と同じ挙動を示し，A Tase と P I 成分が会合してい ることがわかった。 
4899 ウイルス粒子の DNA ポリメラーゼ

Mechanism of Carcinogenesis by RNA Tumor Viruses, III. Formation of RNA D DNA Complex and Duplex DNA Molecules by the DNA Polymerases of Avian Myeloblastosis Virus

K. Fujinaga, et al.: Inst. for Mol. Virol., Saint Louis Univ. School of Med., Proc. Natl. Acad. Sci. USA, 67, (3) 1432 9 (1970)

前報に記した方法で，すなわち ${ }^{3} \mathrm{H}-\mathrm{dTTP}$ の酸不溶 性画分へのとりこみで AMV ウイルス粒子に DNA ポリメラーゼ活性のあることを見出した。本反応はさ きに報告された RNA 依存 DNA ポリメラーゼの例 とは異なり, biphasic な kineticsを示す。生成物を $\mathrm{Cs}_{2} \mathrm{SO}_{4}$ 密度勾配遠心にかけた結果, RNA・DNA hybrid および template-freeの DNA よりなり，後 者は, ハイドロキシアパタイトクロマトの挙動から, 二 本鎖の, しかもその多くはへアピン構造等をもつこと がわかった。以上のことからこのビリオンには RNA 依存および DNA 依存の両 DNA ポリメラーゼ活性 が存在していると思われる。

(西川)

\section{1 細菌 DNA 合成の選択的阻害乳}

6-(p-Hydroxyphenylazo)-Uracil: A Selective Inhibitor of Host DNA Replication in PhageInfected Bacillus subtilis

N.C. Brown: Dept. of Cell Biol. and Pharmacol., Univ. of Maryland School of Med., Baltimore, Proc. Natl. Acad. Sci. USA, 67, (3) 1454 61 (1970)

6-(p-ハイドロキシフェニルアゾ)-ウラシル-HPUra は枯草菌のタンパク合成( U- ${ }^{14} \mathrm{C}-\mathrm{L}-$ ロイシンの熱 TCA

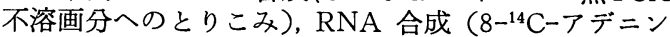
の TCA 不溶, アルカリ可溶画分へのとりこみ)に影響

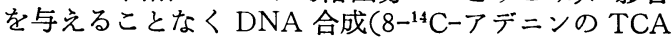
不溶，アルカリ不溶画分へのとりこみ）を選択的に， そして可逆的に阻害する。ところが HPUra 存在下に 枯草菌にビルレントファージ SP3を感染させた場合, 感染後 15 分から ${ }^{14} \mathrm{C}$-チミジンのとりこみが急上昇し, 子ファージの産生も対照並みに行なわれ，HPUra 感 受性の場がバクテリアに特有であることが示された。

(西川)

\section{3 栄養価に及ほす放射性物票除去の影響}

Beurteilung pflanzlicher Lebensmittel nach Behandhungen zur Beseitigung der radioactiven Kontamination

K. Panlus: Bundesforschungsanstalt für Lebensmittelfrischhaltung, Karlsruhe, Z. LebensmittelUntersuch. u. -Forsch., 142, (1) 17〜24 (1970)

放射性物質污染果実および野菜において污染除去処 理がいかに栄養価に影響するか検討した。葉菜は水ま たは $0.1 \%$ エン酸溶液中で $90^{\circ} \mathrm{C}, 30$ 分の加熱で ${ }^{138} \mathrm{Cs}$ は90〜 $100 \%,{ }^{85} \mathrm{Sr}$ は75〜90\%除去され，水中で $90^{\circ} \mathrm{C}$, 10 分加熱後 $20^{\circ} \mathrm{C}$ の水で 60 分すすぐとそれぞれ 85〜95 $\%, 70$ ～ $80 \%$ 除去された。ジャガイモは水中で $90^{\circ} \mathrm{C}$, 40 分の加熱で約 $80 \% ， 60 \% ， 0.2 \%$ クエン酸溶液中で $70^{\circ} \mathrm{C} ， 3$ 時間の加熱で95\%以上，85\%除去された，除 去処理により乾物, アスコルビン酸, タンパクは葉菜 で35〜 46, 35〜98, 26〜43\%, ジャガイモで 7〜26, 35〜96, 13〜48\%それぞれ失われた。
4900 リボソームのアッセンブリー

Structure and Function of Bacterial Ribosomes Xl. Dependence of $50 \mathrm{~S}$ Ribosomal Assembly on Simultaneous Assembly of $30 \mathrm{~S}$ Subunits

H. Nashimoto, M. Nomura: Lab. of Genet. and Inst. for Enzyme Res., Univ. of Wisconsin, Madison, Wis., Proc. Natl. Acad. Sci. USA, 67, (3) $1440 \sim 7$ (1970)

Str 耐性の E. coli から SPC 耐性株(30Sが変化)を 得るとその多くは低温感受性であった。これらの変異 株を $42^{\circ} \mathrm{C}$ 生育させたのち $20^{\circ} \mathrm{C}$ 移し, 培地に ${ }^{3} \mathrm{H}$-ウ ラシルを加えインキュベートし集菌し，そのアルミナ 破砕液に，親株から調製した ${ }^{14} \mathrm{C}$ ーラベルの対照をまぜ ショ糖密度勾配遠心分析すると“30S” 付近と“ $20 \mathrm{~S}$ ” 付 近にピークをもつ変異株が見つかった。両ピークから RNAを抽出して調べるとそれぞれ $23 \mathrm{~S}, 17 \mathrm{~S}$ であり, “20S” 粒子には $30 \mathrm{~S}$ 亜粒子のタンパクの5ち8〜9種 しかなかった。このことから50S亜粒子のアッセンブ リーには30 S 亜粒子が同時にアッセンブリーすること が必要であることが示唆される。

(西川)

\section{2 カイコの系統間の X 線ならびに UV 感受性}

Strain Sensitivity of Silkworm Eggs to Killing and Mutation by Ultraviolet Light

Akio Murakami: Natl. Inst. of Genetics, Misima, Sizuoka-ken, Radiat. Res., 44, (1) 146 53 (1970)

X線感受性を異にするカイコの数系統の卵母細胞と 卵分割細胞のUV 感受性を致死効果と突然変異率を指 標として分析した結果, 系統間で数倍程度異なること が認められた。両生物効果に打いてX線感受性系統は 必ずしもUV 感受性が高くはなく，またX線抵抗性 系統ですUVには感受性が高い系統が観察された。 これは両放射線の生物作用が異なることを示唆する。 X線において致死効果の感受性が高くても突然変異誘 発には抵抗性を示す系統が観察されたが, UV に扣い ては例外なく致死効果について感受性の高い系統は突 然変異率它高切。

（村上）

\section{4 添加保存料の食品残存量について}

Untersuchungen mit ${ }^{14} \mathrm{C}$-markierten Pyrokohlensäurediäthylester 1. Mitteilung Ruckstandsmengen in wasser-und alkoholhaltigen Lebensmitteln

E. Fischer: Inst. für Strahlentechnol. der Bundesforschungsanstalt für Lebensmittelfrischhaltung, Karlsruhe, Z. Lebensmittel-Untersuch. u.-Forsch., 142, (1) $31 \sim 36$ (1970)

保存料ピロカルボン酸ジェチルェステル (PKE) の 食品中残存量（エチルエステルを除く）をしらべるた め, carbonyl-14C-PKEを44種類の市販食品に添加し, 残存している放射能を添加 9 時間〜 4 日まで経時的に 測定した。ビール，ブドウ酒およびシャンパン，果 汁, 果実および野菜から製造した食品の添加 $3 〜 4$ 日 後の残存量は, 添加量のそれぞれ8.5〜37.7\%，3.7〜 $10.8,3.8 \sim 11.1 \%, 3.8 \sim 35.4 \%$ であった。PKE 分 解の副反応の程度には食品の $\mathrm{pH}$ のほかに化学成分 もまた関係があった。

（斎藤） 
3848 Regularization Unfolding in Low (2)(7) Gamma-activity Measurements-I. Evaluation of One-dimensional Scanning G.F. Clemente, et al.: Argonne National Lab., Argonne, Ill., Intern. J. Appl. Radiat. Isotopes, 21, 307〜18 (1970)

生体内の低レベル放射能分布を測ることのできる飛 行時間方式の $\gamma$ カメラの評価と利用について述べる。 この方式のカメラでは放射能の生体内分布とそれに対 応して発生するクリスタル中のシンチレーション光の 分布との間の関係が第 1 種のフレドホルム方程式で表 わされる。この方程式はアンフォールディング法(unfolding method) によって数值的に解くことができる。 本報告では第一報として数值解法の精度に影響する実 験的パラメータの決定について論ずる。実験として一 次元の線状線源をコリメートした 3 in. $\times 3$ in. $\mathrm{NaI}$ 結 晶で測定することを行なった。

(79414)
3849 Diagnosis of Splenic Infarction by (7)(9) Scintillation Scanning with ${ }^{203} \mathrm{Hg}-\mathrm{Bromo}-$ mercurihydroxypropane $\left({ }^{203} \mathrm{Hg}-\mathrm{BMHP}\right)$

D. Alarcon-Segovia, et al.: Immunol. Lab. and Dept. of Rheumatol., Med. and Nuclear Med., Instituto Nacional de la Nutricion, Mexico, D.F., Amer. J. Roentgenol., 109 761 63 (1970)

臨床的に脾梗塞症 が疑われ， l-bromomercuri-2hydroxypropane ${ }^{-203} \mathrm{Hg}$ (BMHP) 処理赤血球で確認 した 2 例について報告した。この例はのちに組織学的 にも証明されたものである。

(79502)
3850 Spinal Cord Dosimetry in ${ }^{131}$ I-HSA (7)(17) Cisternography J.C. Harbert, et al.: Georgetown Univ. Hosp., Washington, J. Nucl. Med., 11, 534〜41 (1970)

蜘蛛膜下腔造影は, とくに水頭症に拈いては被曝の 欠点を補ってあまりある検査法である。15例の患者に $100 \mu \mathrm{Ci}$ の ${ }^{131} \mathrm{I}-$ 血清アルブミンを腰椎穿刺で注入し た。注入後15分から72時間までの間, シンチカメラに 特製スリットを装着して脊髄腔下端から腰椎部までの 間で 2 か所の 5 インチ長の部分の放射能を测定した。 結果は正常人や水頭症の場合, 脊髄表面の線量は中等 度であった。頸髄部閉塞で髄液が少なくないとき，脊 髄表面楾量はかなり大量であった。しかしこの程度の 吸収線量は診断を決定するために時間をかけて透視や X線映画を行なうときにる同様にみられるるのであ る。 (79677)
3851 Evaluation of Spleen Size during (7) Routine Liver Imaging with ${ }^{99 m}$ Te and the Scintillation Camera R.M. Sigel, et al.: New York Hosp., Cornell Med. Center, New York, J. Nucl. Med., 11, 689〜92 (1970)

${ }^{99 m} \mathrm{TcS}$-コロイドを用い321例の肝スキャンより得た 脾影より緃径を得て, 脾のサイズを測定した。その結 果，つぎの範ちゅうを立てることができた。

$$
\text { 重さ } \begin{aligned}
6 \sim 14 \mathrm{~cm} \text { 一正常 } \\
15 \sim 18 \mathrm{~cm} \text { 一腫大 } \\
19 \mathrm{~cm} \text { 以上一一著しく腫大 }
\end{aligned}
$$

(81291)
3852 Controlled Clinical Trial of Com- (8)(15)(3) bined Triiodothyronine and Thyroxine in the Treatment of Hypothyroidism R.N. Smith, et al.: Dept. of Pharmacol. and Therapeutics, Univ. of Sheffield, Sheffield, Brit. Med. J., 4, 145 8 (1970)

2 重盲検交叉法でトリヨードサイロニンとサイロキ シンの合剤 $\left(\mathrm{T}_{3} / \mathrm{T}_{4}=1 / 4\right)$ をあらかじめサイロキシン

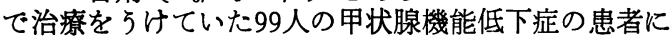
ついて使用し，サイロキシンのみの場合と比較した。 12例は摂取量が不足なため除外した。残り87例中42例 (48\%) は両薬㶡のどちらでもかまわなかった。29例 (33\%)はサイロキシンのは 5 が，16例(18\%)は合風の ほうが結果がよかった。合剤使用群で 2 か月間の投与 で動情, 不安等の症状の出現率が高かったが PBI は 平均 $1.8 \mu \mathrm{g} / 100 \mathrm{ml}$ の低值を示した。 $\mathrm{T}_{3}$ レジンスポ ソジ摄取率は両群ともに変化なく正常範囲にあった。

(81841)
3853 Treatment of Thyroid Cancer.

(8)(15)

Death Rates after Surgery and after Surgery Followed by Sodium Iodine- ${ }^{-131}$ I V.M. Varma, et al.: Dept. of Internal Med. and Pathol., Univ. of Michigan Med. Center, Ann Arbor, Mich., J.A.M.A., 214, 1437〜42 (1970) 263例の分化した乳頭症あるいは口胞状甲状腺がん を手術後 $\mathrm{Na}^{131} \mathrm{I}$ で治療し 0 ２0年 (平均 6.3年) 100 \%追跡調査を行なった。放射線療法導入前の外科療法 患者50例を対照群とし $0 \sim 20$ 年(平均 6.7 年)間追跡調 査をしたすのである。2 群の性分布はよく一致してい るが，年令分布は異なっていた。死亡率をみると40才 以上の患者では $\mathrm{Na}^{131} \mathrm{I}$ 治療群で有意に低かったが, 39才以下の群では両群に有意の差をみとめなかった。

(82033) 


\section{$3854 \mathbf{T}_{3}$ Thyrotoxicosis and the 24-hour}

Uptake of Radioactive Iodine J.D. Wiener: Amsterdam, J.A.M.A., 214, 1566 (1970)

この報告では，24時間 ${ }^{131} \mathrm{I}$ 摂取率は甲状腺機能立進 症, とくにトリヨードサイロニンー $\mathrm{T}_{3}$ 甲状腺中毒症に はあまりよい指標でない。24時間㠌取率に加えてある いはその代わりに早期㠌取率( 3 時間値)あるいは血中 $\mathrm{PB}^{131} \mathrm{I}$ の測定を行なうべきである。この方法を用いれ ば多くの場合に $\mathrm{T}_{3}$ 抑制試験を必要としない。しかし K. Sterling の24時間摄取率の值と無関係に $\mathrm{T}_{3}$ 抑制試 験をスクリーニングテストとするとよいといら考えに は合わないと述へている。

(82036)
3855 Determination of Radiation Dose (8)(15) and Assessment of Clinical Results after Radioiodine Treatment P. Pfannensteil:

Abteilung für Klinische Nuklearmedizin, Medizinische Universitätsklinik, Freiburg, Clearinghouse Fed. Sci. Tech. Inform., RM 849. S 95, 185 205 (1970)

${ }^{131}$ I 治療時の投与量を計算する場合に照射目的組織 のみならず，全身の照射線量をる加味して計算する方 法を考えた。式は簡略化したもので, 計算による治療 量は明らかに他の多くの方法によるものより少なかっ た。治療成績も満足すべきものであり，投与量が少な くてよいことは利点である。核医学的治療は比較的少 量の長期間照射であり, その生物学的効果が, 毎日分 割して照射される体外照射とは異なるもののよ5に考 えられる。

(81965)
3856 The Extrahepatic Uptake of ${ }^{198} \mathbf{A u}$ (11)(7) as an Index of Portal Hypertension J.P. Fernandez, et al.: Georgetown Univ. School of Med. and the Divisions of Cardiology and Gastroenterol. of Georgetown Med. Service, Amer. J. Dig. Dis., 15, 883〜92 (1970)

び慢性の慢性肝疾患において, ${ }^{198} \mathrm{Au}$ 肝スキャンは 安全かつ有用な, 門脈高圧症の診断法である。20例を wedged hepatic vein pressure 测定, 肝スキャンで测

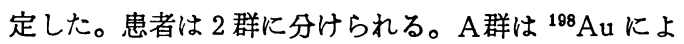
り脾・骨髄の描出のなかったもの。B群はそれが描出 されたるのである。A群の6例の患者のいずれるが hepatic wedge pressure は $18 \mathrm{~mm} \mathrm{Hg}$ 以下で, いずれ 食道静脈瘤を有しなかった。B群の14例は全例 wedge pressure が $18 \mathrm{~mm} \mathrm{Hg}$ またはこれを越え，8 例が食道静脈瘤を有していた。

(80623)

\section{Pitfalls in Liver Photoscans}

(11)(7)

E.E. Covington: Radioisotope Service, Memorial Hosp., New York, Amer. J. Roentgenol., 109, $745 \sim 8$ (1970)

疑陽性および疑陰性所見について検討するため 1000 例の畈のフォトスキャンを行なった。疑陽性スキャン は(1)胆裹窩, (2)腫瘍の圧痕, (3)下大静脈窩, (4)肝門, (5)正中部の脊椎圧痕, (6)左葉ひ薄化, (7)解剖学的な形

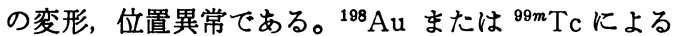
疑陽性スキャンにひき続き ${ }^{131} \mathrm{I}$ ーローズベンガルスキャ ンを行ならと誤診を減ずることができる。疑陰性スキ ヤンは手術時, または剖検時に以下の例で見出され た。 $3 \mathrm{~cm}$ 径以下のすべての転移性がん, $4 \mathrm{~cm}, 6 \mathrm{~cm}$, 時 にはそれ以上の転移がんす見出されぬことがあった。 コンピュータ,数量的レコード方式の導入と多量の RI の使用などで将来改善が期待される。

(79511)

\section{Radiologic Diagnosis of Splenic (11)(7)}

Metastases M.R. Gould, et al.: Dept. of Radiol., St. Vincent's Hosp. and Med. Center, New York, Amer. J. Roentgenol., 109, 755 60 (1970)

転移性脾腫浧の診断例 3 例をのべている。2 例は転 移性の黒色腫で, 病症, 肺転移, 腹部単純撮影の脾の 不整形腫大より確診が必要となった。 ${ }^{99 m} \mathrm{TS}$ ーコロイド スキャンにより, 転移が明らかとなった。3 例目は播 種性の reticulum cell sarcoma の症例で, 同じくス キャンにより，脾内転移が明らかとなった。

選択的血管造影法によりこのスキャンの所見は5ら づけらた。

(79501)

\section{Liver Tumors in Infants and (11)(7)}

Children H. Nikaidoh, et al.: Dept. of Surg. and Pathol., Children's Memorial Hosp., Chicago, Arch. Surg., 101, 245〜57 (1970)

小児の腹部腫瘤の皁期診断には, $\mathrm{X}$ 線とスキャニン グによる。積極的な診断が必要である。シカゴの Children's Memorial Hospital では 1954 年来, 肝原 発性腫場22例，5ち11例がヘパトーム，5例が良性腫 湯、6 例が血管性異常であった。へパトーム群では 5 例の肝葉切除, 1 例の腫場除去および肺転移の肺葉切 除 2 例が行なわれた。残りの 5 例には外科処置は不可 能であった。これらの症例の全例は死亡したが外科手 術後の最長の生存期間は 3 年 4 か月であった。良性腫 場は, 手術後も全例生存した。血管性の腫瘍は著明な 血行動態への影響を起こした。 
3860 Biological Tests of Pharmaceutical (11)(6)

Radio Colloids J.J. Chivot, et al.: Lab. Med., Commissariat a l'Energie Atomique, Paris, Intern. J. Appl. Rad. Isotopes, 21, 459 69 (1970)

放射性コロイド静注後の除去率を測定するため一㑡 性 carotid-carotid 循環法を用い以下の值を求めた。 $K_{8}$ : 貪食恒数, $K_{H}$ : 体外よりの肝測定で計算した恒 数。 $20 \mu \mathrm{g} / 100 \mathrm{~g}$ のコロイドをラットに静注すると 20 $\sim 40 \mathrm{~nm}$ の直径の粒子では $K_{s}=0.254, K_{H}=0.268$, $3 \sim 5 \mathrm{~nm}$ の粒子では $K_{8}=0.112, K_{H}=0.119,5 \sim$

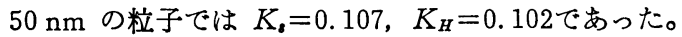
$2 \mathrm{mg} / 100 \mathrm{~g}$ の ${ }^{13.1} \mathrm{I}-\mathrm{CA}$ を静注すると $K_{\mathrm{s}}=0.132$ (ラ ット)， $K_{8}=0.200$ (モルモット) であったが加熱時間 により $K$ ，は非常に異なる。この方法は製品の検定, 製品の応用法の決定に有用なるのである。（81186）
$3861{ }^{{ }^{99 m}}$ Tc-Technetium Dioxide for Liver (11)(7) Scanning A.E. Johnson, et al.: Veterans Administration Hosp. and Univ. of Miami School of Med., Miami, Fla., J. Nucl. Med., 11, 564 $\sim 65$ (1970)

${ }^{99 \mathrm{~m}} \mathrm{TcO}_{4}$-を化学的に還元することにより, 不溶性 の ${ }^{99 m} \mathrm{TcO}_{2}$ の沈殿をうることができる。この沈殿物は $0.5 \mu$ 径の均一の粒状を示している。静注後 $85 \%$ は肝 に集まりよいスキャンをうることができる。 ${ }^{99 m} \mathrm{TcO}_{2}$ は肝内で酸化され可溶性の ${ }^{99 m} \mathrm{TcO}_{4}-$ となり, 排泄さ れる。 ${ }^{99 m} \mathrm{TcO}_{2}$ の粒子の均一性と, 可溶性の ${ }^{99 m} \mathrm{TcO}_{4}^{-}$ を欠くことは, 現在入手しらる放射性コロイドよりす ぐれた肝血流测定用の試薬となりうるであろう。

(79650)
3862 Diagnosis of Constitutional Hyper- (11)(7) bilirubinemia Using ${ }^{131}$ I-BSP Sequential Scanning Method M. Iio, et al.: Univ. of Tokyo, Tokyo, J. Nucl. Med., 11, 633 34 (1970)

しばしば鑑別診断の困難な体真性過ビリルビン血症 の診断基準として, ${ }^{131} \mathrm{I}-\mathrm{BSP}$ の経時的スキャニング法 を導入した。 ${ }^{131} \mathrm{I}-\mathrm{BSP}$ (mono-iodide) は $0.244 \mathrm{mCi}$ / $\mathrm{mg}$ の比放射能を有し, 安定な標識でダイナボット社 にて調製された。 ${ }^{131} \mathrm{I}-\mathrm{BSP}$ の経時的スキャンの利点 は, 肝洞の転送機転, 胆細管への分泌機転を可視化し 万る点である。Dubin-Johnson 症候群では ${ }^{131} \mathrm{I}-\mathrm{BSP}$ は急速に肝に摄取されるが，旰外排泄に著しい遅延が みられた。Rotor 症候群では ${ }^{131} \mathrm{I}-\mathrm{BSP}$ の肝攝取は遅 延を示したが, 旰外排泄は正常で, 両群は明らかに区 別される。 ${ }^{131} \mathrm{I}$ ーローズベンガルではこのような鑑別は できなかった。

(80526)
3863 Scintigraphic and Colloid Clearance (11)(7) Determination of Blood and Liver Dynamics with Lipid Emulsion T. Saba, et al.: V.A. Hosp., Hines, Ill., J. Nucl. Med., 11, 641 (1970)

${ }^{131} \mathrm{I}$-トリオレイン，グリセロール，レシチンの 10: 10:1無水エマルジォンを作製，5\%のブドウ糖液に混 和して静注した。イヌではこの lipid emulsion は肝 の網内系により急速に摂取され, $100 \mathrm{mg} / \mathrm{kg}$ の負荷量 は, 急速相の $t_{1 / 2} 2.1 \pm 0.1$ 分, 緩徐相 $8.3 \pm 2.7$ 分で クリアランスされる。静注50分後の組織内分布は, 肝 で $185 \pm 5 \mathrm{mg} / 100 \mathrm{~g}$, 脾で $54 \pm 19 \mathrm{mg} / 100 \mathrm{~g}$, 肺で $25 \pm 7$ $\mathrm{mg} / 100 \mathrm{~g}$ である。lipid emulsion は肝で代謝され遊 離し, 注入後15〜18分で, 循環中に再出現する。この 無毒性の fat emulsion は, 肝血流量, 肝網内系の研 究にまた肝の描出に利用しうる。

(80529)
3864 Growth of the Human Liver: $A$ (11)(7) Preliminary Scan Study R.P.Spencer, et al.: Yale Univ. School of Med., New Haven, Conn., J. Nucl. Med., 11, 660 2 (1970) ${ }^{99 m} \mathrm{~T} c-S$-コロイド, ${ }^{198} \mathrm{Au},{ }^{131} \mathrm{I}$-ローズベンガル等を 使用して小児に実施したスキャンより肝の長経, 巾, 前額断面積などを測定した。この值を小児の年令, 身 長, 体重, 体表面積と比較した。直線的関係が肝長経 と表面積, 巾などの間にみられ, 肝の長経/巾比は 0.7 〜1.2の間にあった。体重が $30 \mathrm{~kg}$ を越えると肝測定值 の増加率は減少する。これは9才（または体重 $30 \mathrm{~kg}$ ) ごろに起こる体重増加率の増加によると考えられる。 しかし，肝長経は年令，身長と平行して増加する。

すなわち十分の症例が得られれば肝の生長に関する 推定值が得られ，スキャンが正常值であるか不か予測 できることとなろう。

(81287)
3865 Angiography and Scanning in (11)(7) Liver Disease P. Rossi, et al.: Dept. of Radiol., St. Vincent's Hosp., N.Y., Radiol., 96, $553 \sim 62$ (1970)

105例の患者に肝スキャン, 腹腔動脈または肝動脈 造影法を行なった結果77例に確定診断がなされた。こ のうち26例は space occupying mass であり, 35例は 肝硬変症である。この両方法を比較すると, (a) 2 方法 は相補的であり，スキャンはスクリーニングの目的に すぐれている。(b)血管造影法は通常情報量が多く, よ り小さな肝内障害部を描出しらる。(c)血管造影法はと くに肝硬変症の存在下においてはいわゆる pseudotumor から真性腫瘍を鑑別するのに有用である。(d)経 動脈化学療法を実施する前には, 血管造影法が必要で ある。著者らは現在では dual 5 inch scanner を入手 し, ${ }^{99 m} \mathrm{TcS}$-コロイドを用いて 4 面のシンチを行なっ ている。 
3866 The Diagnostic Value of Hepatic (11)(7) Pliability as Assessed from Inspiration and Expiration Views on the Gamma Camera J.K. Kranzler, et al.: Dept. of Radiol., Surg. and Pathol., Pritzker School of Med., Univ. of Chicago for U.S.A.E.C., Chicago, Ill., Radiol., 97, 323 6 (1970)

数 $\mathrm{mCi}$ の ${ }^{99 \mathrm{~m}} \mathrm{Tc}$-コロイドと Anger camera の使 用で，肝の前額面スキャン (100,000 count) が 20 秒 内外で得られる。これを深吸気時または深呼気時に行 な党ば, 肝の形の変化度 (柔軟性) を検することがで きる。肝の柔軟性の欠除は $95 \%$ 以上の確実性をるって 病的である。時には柔軟度の欠除が唯一の異常所見で あることがある。柔軟度の衰乏は，線維症，細胞浸潤 (たとえば白血症), 浮腫, また横隔膜下おょび後腹壁 の病巣の肝への傯着によって起こる。しかし, 柔軟性 は転移性腺がん脂肪肝では維持される。方法も簡単 であり，有用な検查法と考える。

(81337)
3867 Change in Colloidal Gold Clearance in (11) Rats Treated with SKF 525-A C. Marchand, et al.: Dept. de Pharmacol., Faculte de Med., Univ. de Montreal, Canada, Rev. Can. Biol., 29, 293 98 (1970)

ラッテを 2-diethylaminoethyl-2, 2-diphenyl valerate hydrochloride (SKF 525-A) で処理すると, ${ }^{198} \mathrm{Au}$ ーコロイドのクリアランスが遅延し, 肝血流量の 低下を示唆する。

SKF 525-A (proadifen hydrochloride) $30 \mathrm{mg} / \mathrm{kg}$ 腹腔内注入 40 分後に尾静脈より ${ }^{198} \mathrm{Au}$ 溶液 $0.25 \mathrm{ml}$ を 注入した。SKF の drig metabolizing enzyme activity の抑制剂としての因子のなかにはこの盰血流量 の減少をも考㦄すべきであろう。

(80727)
3868 Two-step Scan with a Differential (11)(7) Physiological Principle in a Transformation of the Liver Cirrhosis J.Th. Locher, et al.: Nuklearmed. Abteil. des Universitatsröntgeninstituts, Burgerspital, Basel, Schweiz Med. Woschr., 100, 1599 1603 (1970)

通常のスキャンの価值のあまりない進行性肝硬変症 診断に応用する two-step scan 法についてのべてい る。通常のスキャンが不正確な理由は局所血流の減少 と, RES 系の不全である。このさい ${ }^{131}$ I-rose bengal を用いる代わりに ${ }^{75} \mathrm{Se}-$ selenomethionine を用いるこ とをすすめるすのである。 ${ }^{75}$ Se-selenomethionine は 肝細胞に急速にとりこまれ，かつそこに長くとどまる のでスキャンに適している。通常のコロイドの貪食に よる局所欠損の診断のほかに肝細胞系の機能障害を知 ることは, 診断上重要である。

(80878)
3869 Serial Scans of Liver Regeneration (11)(7) after Hemihepatectomy in Children L.D. Samuels, et al.: Dept. of Pathol., Ohio State Univ., Columbus, Ohio, Surg. Gynecol. Obstet., 131, 453 7 (1970)

Hemihepatectomy 後10日から10年にわたって, 経 時的肝スキャニング法により, 肝の形態学的変化と再 生過程を検討した。 ${ }^{131} \mathrm{I}$ ーローズベンガル $40 〜 80 \mu \mathrm{Ci}$ または $0.25 〜 2.5 \mathrm{mCi}$ の ${ }^{99 m} \mathrm{TcS}$ コロイドを静注し た。スキャン像は前面扰よび後面よりとり, ${ }^{99 m} \mathrm{TcS}$ コロイドでは脾影も描出した。肝脾の境界の不明のと

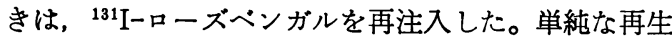
過程および複雑な再生過程を例示する。本法により, 予期しえなかった合併症が予测しえ，また再生過程の 形態を知ることができる。

(79686)
3870 Liver Scans after Primary Treat- (11)(7) ment of Tumors in Children L.D. Samuels, et al.: Dept. of Pathol. and Surg., Div. of Pediatric Surg., Children's Hosp. Columbus, Ohio, Surg. Gynecol. Obstet., 131, 958 64 (1970)

小児の肝に ${ }^{60} \mathrm{Co}$ などより $2,000 \sim 3,000 \mathrm{rad}$ の 照射を分割的に $2 \sim 3$ 週にわたって浴びると，きわめ て感受性が高く肝細胞, 肝網内系も, 放射能の摄取 が減じ，萎縮を生ずるに至る。右腎部の放射線療法の 結果, 左葉優勢の肝となった症例の報告がある。小児 では以前に信じられていたほど肝は放射線耐性の強い 臓器ではない。 (81252)
3871 Regional Myocardial Perfusion in (12) Patients with Coronary Artery Disease P.J.Cannon, et al.: Columbia U. College of Physicians and Surgeons, New York, N.Y., Cardiovasc. Res., 4, 98 (1970)

臨床例において ${ }^{133} \mathrm{Xe}$ 生食溶液を冠状動脈内に注入 し, 多数のクリスタルによるシンチレーションカメラ により心筋の多くの部分のクリアランス曲線群を同時 に測定し，クリアランス定数 $(k)$ を比較することによ り，心筋局所血流量の比較を行なった。正常例におけ る心筋血流量は 46〜 $105 \mathrm{ml} / 100 \mathrm{~g}$ であり, 左室>右 室〉心房の順であった。冠状動脈造影上病変が軽微で あるか, あるいは側副血行路の発達している心筋部で は， $k$ は正常であったが, 高度の狭窄により末梢部で は $k$ 值は低下し，冠状動脈疾患例のあるるのでは，心 筋血流量が不均等であると考えられる。

(81645) 
3872 The Measurement of Myocardial (12) Blood Flow in Patients Undergoing Selective Coronary Arteriography D.C. Fluck, et al.: Cardiovasc. Res., 4, 138 (1970)

1969年 2 月以来 Guy 病院では選択的冠状動脈造影 法にさいし, ${ }^{133} \mathrm{Xe}$ 法による心筋血流量測定法をも同 時に施行している。血流量の测定は冠拡張 薬投与前 と, 最大の冠血流量増加をきたすと考えられる量の dipyridamole を投与したのちにも繰り返して行なう。

拡張薬投与前には, 正常者之冠状動脈造影上, 狭窄 あるいは閉塞をみる例との間に血流量の差を認めない が, dipyridamole 投与後, 右冠状動脈における 血流 量は, 疾患例に打いて低值を示した。本法は造影法と 並んで, 虚血性心疾患例の判定上有用で, かつ安全な 検查法である。

(81656)

3873 Intractible Congestive Failure (12)(15 Treated with ${ }^{131}$ I Thyroid Ablation J.G.

Schlichter: Med. Dept., Northwestern Med. School and Michael Reese Hosp. and Med.

Center, Cardiovasc. Res., 4, 278 (1970)

心筋疾患, 冠動脈疾患, あるいはリュウマチ性心疾患 による難治の5っ血性心不全例16例に 対して, ${ }^{131} \mathrm{I}$ 投 与による甲状腺除去療法を行なった成績を報告する。

粘液水腫となった症例はなく, 症例として心筋障害 を主とする例を選択したので，全例とす治療により IV 度より II 度への軽快を示した。平均生存期間は 4 年 で, おるな死因は不整脈と心筋梗塞の再発であった。

注意深い患者の選択と, 慎重な経過観察が生存期間 を延長する秘訣と思われる。

(81410)

3874 Measurement of Serum Digoxin (12) Concentration by Radioimmunoassay: Clinical Applications T.W.Smith, et al.: Cardiac Unit, Dept. of Med., Mass. General Hosp., Boston, Mass., Cardiovasc, Res., 4, 289 (1970)

著者らは血清ジゴキシン濃度を測定するために，迅 速, 正確, かつ特異的な放射免疫学的な定量法を考案 した。腎機能が正常で, ジゴキシン中毒の徴候のない 症例で $0.25 \mathrm{mg} /$ 日および $0.5 \mathrm{mg}$ /日服用例の平均濃度 はそれぞれ1. $2 \pm 0.4 \mathrm{~m} \mu \mathrm{g} / \mathrm{ml}, 1.5 \pm 0.4 \mathrm{~m} \mu \mathrm{g} / \mathrm{ml}$ であ り, 中毒症状を呈する 48 例の平均濃度は $3.5 \pm 2.4$ $\mathrm{m} \mu \mathrm{g} / \mathrm{m} l$ と有意に高值を示した。中毒例の 5 ち伝導障 害を呈する例に比し, 異所性刺激生成による不整脈例 は有意に高值を示し，また中毒例では尿素窒素含量の 有意な増加が認められた。700 例に おける1500回以上 の測定成績より，本法が臨床的に有用であることが証 明された。

(81412)
3875 Myocardial Blood Flow in Pacing- (12)

Induced Angina C.R. Conti, et al.: Dept. of Med., Cardiorvascular Division, Johns Hopkins Univ. School of Med., Baltimore, Md., Circulation, 42, 815 25 (1970)

27例に拈いて，心臟ペーシングにより頻脈とし， ${ }^{133} \mathrm{Xe}$ を左冠状動脈に注入して心筋血流量を測定する とともに，13例においては心筋酸素消費量をる測定し た。10例では頻脈時に狭心痛， あるいは虚血性心電困 変化を示したが，これらの症例では心筋血流量，心筋 酸素消費量はそれぞれ $32 \mathrm{ml} /$ 分 $/ 100 \mathrm{~g}, 4.63 \mathrm{ml} /$ 分/100 $\mathrm{g}$ の増大を示したのに対し，虚血性反応を示さなかっ た17例では, それらの増大は $12 \mathrm{ml}, 2.62 \mathrm{ml}$ と有意 に低值を示した。以上の予想に反する成績は，虚血に 対する反応として，著明な血管拡張による非虚血部心 筋血流量の増大として説明されよう。

(81259)
3876 The Use of ${ }^{131}$ I Fibrinogen in the (12) Diagnosis of Venous Thrombosis A.P.C. van der Maas, et al.: Bergwegziekenhuis, Internal Dept. Rotterdam, Holland, XIII Intern. Congr. Hematol., Lehmanns Verlag, 371 (1970)

Kabi 線維素を ${ }^{131} \mathrm{I}$ により標識し, 純化し精製した ものを用いた。正常例 15 例における半減期は3.56士 0.67 日であるのに対し, 静脈血栓症例13例に括ける半 減期は $2.52 \pm 0.54$ 日であり, 抗凝固剂療法後 $3.92 \pm$ 0.62 日に延長した。また ${ }^{131} \mathrm{I}$ 線維素投与 3 日後に両側 下肢のスキャンを行なったが, 静脈血栓が臨床的に明 らかである症例では, 患肢上に放射能の上昇を認め た。小さい肺塞栓を示すが臨床的に下肢静脈血栓の所 見を呈しない4例では，下肢のいずれにおいてる放射 能増大を認めなかった。以上のごとく, 静脈血栓の診 断にさいしては, スキャン法より半減期を求めるほ がすぐれている。
(81724)
3877 Myocardial Uptake Studies with (12)(7) ${ }^{129} \mathrm{Cs}$ and the Scintillation Camera Y. Yano, et al.: Donner Lab. and Lawrence Radiation Lab., Univ. of Calif., Berkeley, Calif., J. Nucl. Med., 11, 663 8 (1970)

${ }^{129} \mathrm{Cs}$ の製法を述べ，ヒトならびに実験動物におい て, $500 \mu \mathrm{Ci}$ の ${ }^{129} \mathrm{Cs}$ と混在する $0.15 \mu \mathrm{Ci}$ の ${ }^{22} \mathrm{Na}$ を投与するさいの両者により全身の照射量を記載し た。またイヌでは ${ }^{129} \mathrm{Cs}$ 静注 1 時間後に消化管で最大 の摂取量がみられ, 照射量最大の臓器は腎であった。 ラットでは ${ }^{129} \mathrm{Cs}$ の心/血液比は時間とともに増加 し, 心/肝比は減少を示した。最大の心筋摂取率をみ るのは静注40ないし90分後と考えられる。

イヌで冠動脈分枝を結紮し ${ }^{129} \mathrm{Cs}$ により筋シンチ フォトを撮影した成績と 6 例の臨床例における所見に ついても述へ，本法の冠動脈血流量の定量化，虚血部 の表示, 薬剤の反応への応用に言及した。（81288） 
3878 Digoxin: Immunologic Approaches (2) to Measurement and Reversal of Toxicity V.P. Butler, Jr.: Dept. of Med., Columbia Univ. College of Physicians and Surgeons, New York, N.Y., New Eng. J. Med., 283, 11 50 6 (1970)

著者は放射性免疫法によりジゴキシン服用患者の血

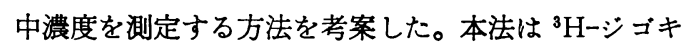
シンの約 $50 \%$ と結合する少量のジゴキシン抗体を用

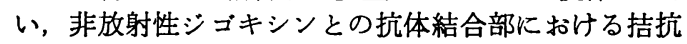
作用を利用したもので, ジゴキシン濃度 $0.2 \mathrm{~m} \mu \mathrm{g} / \mathrm{m} l$ まで测定しらる。

また本法は特異的であり，ジギタリス剤を服用して いない例では陽性とならず，また数時間以内に結果を しることができるなど，ジギタリス剤中毒例に応用し らる重要な条件を備えている。

(81365)
3879 Implantable Nuclear-Powered (12) Cardiac Pacemakers J.C. Norman, et al.: Dept. of Surg., Harvard Med. School, Mass., New Eng. J. Med., 283, 1203 6 (1970)

現在用いられている心臓ペースメーカーは寿命が短 く，高価であるので，それに代わるるのとして放射性同 位元素をエネルギー源とし，それより発生する熱を電 気に変換して駆動する心臟ペースメーカーが検討され ている。使用される放射性同位元素としては ${ }^{238} \mathrm{Pu}$ が 種々の理由より最適とされているが， ${ }^{147} \mathrm{Pm}$ もまた用 いられている。イヌによる動物実験では，放射線照射 量は無視しらるぐらい微少で， 2 年後の成績では線源 周辺 $6 \mathrm{~mm}$ の組穖にわずかな変化を認めるのみで，全 身的な影響は考えられない。最初の価格は約 $\$ 3,000$ であるが, 燃料カプセルの安全性が目下の問題とされ る。

(81587)

\section{Visualization of Mediastinal}

(2)(7)

Lymph Nodes after Intraperitoneal Administration of ${ }^{99 m} \mathbf{T c}$-Sulfur Colloid H.L.

Atkins, et al.: Med. Res. Center and Dept. of Applied Sci., Brookhaven National Lab., Upton, L.I., N.Y., Nucl. Med., 9 (3) 275 8 (1970)

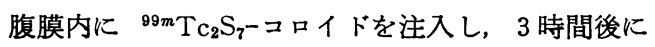
綐隔リンパ節を描出することが可能である。家兔で は, 縦隔リンパ節の ${ }^{99 m} \mathrm{~T} \mathrm{c}$ 放射能は注入 3 時間後で も十分に高く，24時間後と同様であった。実例として は，43才乳がんの女性に ${ }^{90 m} \mathrm{Tc}$-コロイド $2.2 \mathrm{mCi} / 20$ $\mathrm{m} l$ を左腹腔内に注入し, $2 \frac{1}{2}$ 時間後にアンガー・カ メラでシンチグラフィを行なった。アンガーカメラは 深度の異なるリンパ節をスキャンよりる良く描写し得 る。 (81271)
3881 Retension and Excretion of $\mathbf{H g}-203$ (14) Labeled Methyl Mercury in Man after Oral Administration of Methylmercury Biologically Incorporated into Fish Muscle Protein J.K. Miettinen, et al.: Dept. Radiochem., Univ. Helsinki, Finland, Scand. J. Clin. Lab. Invest., 25, (Suppl. 113) 97 (1970)

タンパク結合メチル水銀の体内残留, 排泄を ${ }^{203} \mathrm{Hg}$ 標識物質を投与して全身計測装置で調べた。 $2 \mu \mathrm{Ci}$ の ${ }^{203} \mathrm{Hg}$ 一メチル水銀をたべさせた魚の筋肉を 15 人の協力 者に経口投与し, 鉄室内の 4 in. $\times 8$ in. $\mathrm{NaI}$ 結晶で全 身計測を行ない, 尿, 大便, 血液を採取した。大便中 の ${ }^{203} \mathrm{Hg}$ は, 尿中上り多く，3〜4日で $6 \%$ か吸収さ れずに排泄される。赤血球中の濃度ははじめ急速に減 少し平均半減時間は $50 \pm 7$ 日, 全身計測法に上る全身 の生物学的半減期は76士10日であった。

(81004)
3882 Normal-Pressure Hydrocephalus. (17)(7) Role of Cisternography in Diagnosis A.E. James, Jr., et al.: Div. of Nucl. Med., Johns Hopkins Med. Inst., Baltimore, JAMA, 213, 1615 22 (1970)

正常圧水頭症は治療可能な痴呆症ゆ之, 臨床症状, そ の他の検査が不可欠である。本症の特徵は, 痴呆, 運 動障害, 正常髄液圧, 脳萎縮のない脳室拡大であり, 気脳写では脳室の抾大と脳表に空気がはいらぬことが みられる。蜘蛛膜下腔写では拡大した脳室内に放射能 が集まること, 脳表部放射能分布の異常, 遅い時期で も矢状部に放射能集積がみられぬことなどである。 ${ }^{90 m} \mathrm{~T}$ c-血清 albumin は短時間での像をみるのに良い が, 半減期が 6 時間のため遅い時期でのスキャンには 不向きである。このために, ${ }^{131} I$-血清 albumin や DTPA ytterbium chelate ${ }^{-169} \mathrm{Yb}$ がよく使われる。
3883 Scintillation Visualization of a (17)(7) Vascular Rim in Subdural Hematoma

W.M.Smoak, et al.: Univ. of Miami School of Med., Miami, J. Nucl. Med., 11, 695 7 (1970)

${ }^{{ }^{90 m} T}$ c によるシンチカメラで, 硬膜下血腫とあとで 判明した例において, 動的, 静的検查とるに脳血管の 圧排を観察した。压排されたところは境界の明らかな 放射能増加で, 半楕円形のふちの形をしている。硬膜 下血腫のシンチフォトに扑けるこのふち徴候は臨床所 見として重要であると思われる。この徵候の病態生理 を論じ，また，硬膜下血腫のシンチ所見で， ${ }^{203} \mathrm{Hg}$ を 使った場合と ${ }^{99 m} \mathrm{Tc}$ を使用した場合の差を指摘した。

(81293) (79680) 
3884 Brain Scans in Multiple Sclerosis (17)(7)

R.W. Gize, et al.: Dept. of Radiol., Section of Nucl. Med., Indiana Univ. Med. Center, Indianapolis, Ind., Radiol., 97, 297 9 (1970) 多発性硬化症の敌床診断がついた 28 例中 5 例の脳ス キャンに腫崵を示唆する異常所見があった。それらは すべて病勢の活動期であった。非活動期だった14例に は一例す異常がなかった。異常放射能集積はすべて 白質に存在した。使用した同位元素は患者の半数が ${ }^{203} \mathrm{Hg}$, 残りの半数が ${ }^{99 m} \mathrm{Tc}$ である。 2 例の症例を呈 示した。

(81334)
3885 Detection of Carotid Artery Ob- (1D) struction by Intravenous Radionuclide Angiography R.J. Griep, et al.: Dept. of Med., U.S.P.H.S. Hosp. and Div. of Nucl. Med., Tumor Inst. of Swedish Hosp. Med. Center, Seattle, Wash., Radiol., 97, 311 16 (1970)

脳血管症状を呈する 49 例において, ${ }^{99 m} \mathrm{Tc} 15 \mathrm{mCi}$ を静注し，シンチカメラにより 3 秒ごと， 8 枚の連続 撮影を行ない, 造影剤を用いた血管造影所見と対比し た。

血管造影上，一方の内頸動脈あるいは総頸動脈閉塞 を示した11例に拈いて，6秒の間当該領域の放射能の 減少を認めた。両側頸動脈の閉塞例 ( 1 例) と狭窄例 ( 2 例) においては, 頸動脈部放射能に左右差を認め なかった。

(81335)
3886 Aseptic Meningitis following the (17) Intrathecal Injection of Radioiodinated Serum Albumin R.K. Oldham, et al.: Dept. of Radiol. and Med., Vanderbilt Univ. Hosp., Nashville, Tenn., Radiol., 97, 317 21 (1970) ${ }^{131} \mathrm{I}$-血清アルブミン (RISA) $100 \mu \mathrm{Ci}$ を腰椎穿刺注 入後に発生した 2 例の無菌性髄膜炎症例を報告した。 両例とも注入したアルブミン量は $2 \mathrm{mg}$ 以下であっ た。後遣症は認められていない。無菌性髄膜炎に関す る簡単な文献考察と, その発生機序を論じた。

(81336)
3887 Testing Ventriculocardiac Shunts (17) with Hippuran- ${ }^{131}$ I P. Makela, et al.: Dept. of Pediatrics and Radiotherapy and Unit of Neurosurg. of Dept. of Surg., Univ. of Turku, Finland, Scand. J. Clin. Lab. Invest., 25, (Suppl. 113) 22 (1970)

脳室一心臓短絡路の機能をみるため, 1969年初めよ り13例に扣いて放射性同位元素を脳室，あるいは弁部 に注入する検査を18回実施した。本法の成績は臨床所 見あるいは手術所見とよく対応を示した。

われわれの病院では, 脳室一心臓短絡路の機能をみ るため, 今後この簡便でかつ安全な本検査をルーチン 検查として実施する予定である。

(80973)
3888 Radionuclide Studies of the Skele- (18)(7) ton in Hemoglobinopathies and Gaucher's Disease D.H. Woodbury, et al.: Sect. of Nucl. Med. and Hematol., Dept. of Med., Wayne County Gen. Hosp. and Univ. of Michigan, XIII Intern. Congress of Hematol., Lehmanns Verlag, p. 139, RB145. I 513, (1970) Hemoglobinopathy や Gaucher 病の発生率, 病因 等の究明のために，著者は ${ }^{85} \mathrm{Sr},{ }^{18} \mathrm{~F}$ を用いた photoscintiscanning を行なってる。得られた所見は臨床所 見, X線, 骨生検, 骨髄検查所見と相関が認められて いる。研究知見につき記載してあるが, 結論として骨 の放射性核種による研究は骨病変の病態生理と骨・骨 髄間相互の影響に関する究明の一助となるであろうと している。 (81498)
3889 Evaluation of Sr-85 Bone Scans (18)(7) with Corresponding Radiographs in 100 Cases T.H.Milner, et al.: Bowman Gray School of Med., Winston-Salem, N.C., S. Med. J., 63, 1371 (1970)

腫瘍患者 100 例を無作為に抽出して, 骨転移巣検出 のための ${ }^{85} \mathrm{Sr}$ 骨スキャンとX線写真の感度の比較を 行なった。全体の $62 \%$ に陽性所見を得たが，38\%がス キャン・X線ともに陽性，17\%がスキャン陽性，X線 陰性，7\%がX線陽性，スキャン陰性という結果であ った。一般に骨スキャンはX線より検出率が高いが， 偽陰性例もあるため転移が強く疑われる場合には両検 查をともに行な5べきであろ5。以上の結果から，根 治治療を行なう前に転移巣の診断を積極的に行ならべ きであることが示唆される。

(81147) 
3890 Lymphnodes Scintigraphy with (21)(7) ${ }^{19} \mathrm{HgCl}_{2}$ in Hodgkin's Disease - E. Ascari, et al.: Inst. Med. Pathol., Univ. Modena, Modena, Italy, XIII Intern. Congr. of Haematol., Lehmanns Verlag, RB 145. I 513, 140 (1970) ホジキン氏病 18 例, ザルコイドーゼ 2 例について ${ }^{197} \mathrm{HgCl}_{2}$ によるシンチグラフィを行ない, 横隔膜上の リンパ腺描写を試みた。ホジキン氏病では全例に48〜 60時間に RI の存在を認めたが, ザルコイドーゼでは 同一期間内にほとんど認めなかった。 RI の存在はそ のリンパ腺が悪性であることを示唆するすのである。 この方法は他の方法では検知できない部位のリンパ腺 の診断に役立ち, 放射線治療の勃果判定にも役立つと 考えられる。

(81502)
3891 Lymphoma: Diagnosis, Staging, and (21)(7) Relapse as Defined by ${ }^{75} \mathrm{Se}-$ Methionine Total Body Scans M.B. Weinstein: Univ. of Miami School of Med., Miami, Fla., XIII Intern. Congr. of Haematol., Lehmanns Verlag., RB 145. I 513, 140 (1970)

${ }^{75} \mathrm{Se}$ 一七レノメチオニンは種々の腫場組織にも選択 的に沈着するので, 全身スキャニングによる病巣の発 見を武みた。症例はリンパ腺腫大を伴う疾患を含む各 種の腫湯症例である。喉頭がんでは原発部位のみなら ず頸部リンパ腺転移をるスキャン像で描写し得た。各 種の甲状腺がんも ${ }^{75} \mathrm{Se}$ 一レノメチオニンを摂取して いた。未治療のリンパ腫大疾患では陽性スキャンが得 られたが，治療により抑制されたものでは陰性スキャ ンであった。

(81503)
3892 Scan Evidence of Organ Involution (21)(7) and Improvement of Hypersplenism in Hodgkin's Disease following Splenic Artery Ligation S.B. Nuland, et al.: Yale Univ. School of Med., New Haven, Conn., J. Nucl. Med., 11, 693〜4 (1970)

ホジキン病で脾剔が適応でない症例に, 脾動脈の結 禁を行なったところ, 脾のサイズは縮少し, 脾機能六 進による血液像の著明な改善, さらに ${ }^{99 m} \mathrm{TcS}$-コロイ ドの正常分布化がみられた。

(81292)

\section{Localization of Gallium-67 in}

(21)(7)

Malignant Neoplasms S.G. Vaidya, et al.:

Radiotherapy Dept. and Med. Res. Council Cyclotron Unit, Hammermith Hosp., Landon, Lancet, 2, 911〜14 (1970)

${ }^{67} \mathrm{Ga}$-citrate の静注により各種の悪性腫瘍をシンチ スキャンで描出できる。20例の検査の結果11例に集積 をみ， 3 例はまったく集積がなかった。他の 5 例はシ ンチスキャンが不十分であった。 ${ }^{67} \mathrm{Ga}$-citrate の腫場 集積は放射線治療後には減少する。

(81051)
3894 Reevaluation of the ${ }^{32} \mathbf{P}$ Eye Tumor (21)17 Identification Test J.H. Larose, et al.: Div. of Nucl. Med., Emory Univ., Atlanta, Ga., S. Med. J., 63, 1372 (1970)

${ }^{32} \mathrm{P}$ を用いる眼腫湟検查は偽陰性が多く利用されて いない。著者の方法は Blahd の教科書と基本的には 同じだが腯場が後方にある場合に対して結膜を切開す る方法を用い。腫湯部および 健常対照部の計数率を GM カウンタで測定する。毛様体および脈絡膜の腫瘍 60 万ち 54 病巣に ${ }^{32} \mathrm{P}$ 検査陽性の結果を得た。このう ち49は悪性黒色腫， 2 例は転移がんであった。3 例は 手術をしていないが臨床的には悪性である。 ${ }^{32} \mathrm{P}$ 検査 が陰性の 9 例中 2 例は組織学的に黒色腫であったがこ の 2 例とす後方腫湯で, 眼球摘出後検出器を病巣に近 づけて測定すると陽性になった。半導体検出器す使用 した。 (81148)
3895 Experience with Parathyroid

(23)(7)

Scintigraphy A.C.Colella, et al.: Dept. of Nucl. Med., Inst. of Radiol, Univ. of Rome, Amer. J. Roentgenol., 109, 714 23 (1970)

副甲状腺シンチグラムの実用化の可能性について ${ }^{75} \mathrm{Se}$-selenomethionine での実験を 34名の原発性副甲 状腺機能六進症で行なって，手術をした15例で術前に その $53 \%$ で機能六進組織の場所を確認した。副甲状腺 のシンチグラフィに影響する,生物学的, 物理学的条件 としては(1)代謝の活発なポリペプチドにメチオニン含 量が少ないので副甲状腺組織が標識了ミノ酸をよくと りこむ。(2)腺腫が大きいはど描出しやすく甲状腺と骨 髄が副甲状腺の描出をじゃまする場合るある。(3)甲状 腺の機能が抑制されているほど副甲状腺が陽性度が大 きくなる。(4)高感度の装置でコントラストをきかせる 必要がある，などが考えられる。

(80085) 